\title{
Assessing the potential of dual-purpose maize in southern Africa: A multi-level approach
}

\author{
Sabine Homann-Kee Tui a,*, Michael Blümmel ${ }^{\mathrm{b}}$, Diego Valbuena ${ }^{\mathrm{c}, \mathrm{d}}$, Albert Chirima $^{\mathrm{a}}$, \\ Patricia Masikati ${ }^{\mathrm{a}}$, Andre F. van Rooyen ${ }^{\mathrm{a}}$, Girma T. Kassie ${ }^{\mathrm{e}}$ \\ a International Crops Research Institute for the Semi-Arid Tropics (ICRISAT), PO Box 776, Bulawayo, Zimbabwe \\ ${ }^{\mathrm{b}}$ International Livestock Research Institute (ILRI), c/o ICRISAT, Patancheru 502 324, India \\ c Systems-wide Livestock Programme (SLP), PO Box 5689, Addis Ababa, Ethiopia \\ d Wageningen University, Farming Systems Ecology, PO Box 563, 6700AN, Wageningen, Netherlands \\ e International Maize and Wheat Improvement Centre (CIMMYT), PO Box MP 163, Mount Pleasant, Harare, Zimbabwe
}

\section{A R T I C L E I N F O}

\section{Article history:}

Received 30 December 2012

Received in revised form 30 June 2013

Accepted 5 July 2013

\section{Key words:}

Feed resources

Maize cultivars

Crop-livestock systems

GIS

Southern Africa

\begin{abstract}
A B S T R A C T
This paper explores the potential and challenges of increasing production of food and feed on existing maize fields in mixed crop-livestock systems in the semi-arid areas of southern Africa. It integrates results from different sources of data and analysis: 1 . Spatial stratification using secondary data for GIS layers: Maize mega-environments combined with recommendation domains for dual-purpose maize were constructed for Malawi, Mozambique and Zimbabwe, stratifying the countries by demand factors (livestock densities and human population densities) and feed availability. Relative biomass contributions to feed resources from rangelands were compared to those from croplands to explore the usefulness of global datasets for feed supply estimations. 2. Verification through farming systems analysis: the potential demand for maize residues as feed (maize cropping patterns, maize yields and uses, feed deficits) was compared at contrasting sites, based on household survey data collected on 480 households in 2010. 3 . Maize cultivar analysis: Genotypic variability of maize cultivars was compared to evaluate the potential contribution (stover quantity and quality) of dual-purpose maize to reduce feed deficits. The study results illustrate high spatial variability in the demand for and supply of maize residues. Northern Malawi is characterized by high livestock density, high human population density and high feed availability. Farmers achieve maize yields of more than $2 \mathrm{t} /$ ha resulting in surplus of residues. Although livestock is important, southwest Zimbabwe has low livestock densities, low human populations and low feed availability; farming systems are more integrated and farmers make greater use of maize residues to address feed shortages. Central Mozambique also has low cattle densities, low human populations and low feed availability. More rangelands are available but maize yields are very low and livestock face severe feed shortages. The investigation of 14 advanced CIMMYT maize landraces cultivars and 15 advanced hybrids revealed significant variations in grain and stover yield and fodder quality traits. Where livestock densities are high and alternative feed resources are insufficient, maize cultivars with superior residue yield and fodder quality can have substantial impact on livestock productivity. Cultivars at the higher end of the quality range can provide sufficient energy for providing livestock maintenance requirements and support about $200 \mathrm{~g}$ of live weight gain daily. Maize cultivars can be targeted according to primary constraints of demand domains for either stover quantity or stover fodder quality and the paper proposes an approach for this based on voluntary feed intake estimates for maize stover.
\end{abstract}

(c) 2013 Elsevier B.V. All rights reserved.

\section{* Corresponding author.}

E-mail addresses: s.homann@cgiar.org, shomannkeetui@gmail.com (S. Homann-Kee Tui),m.blummel@cgiar.org (M. Blümmel),diego.valbuena@wur.nl (D. Valbuena), a.chirima@cgiar.org (A. Chirima), p.masikate@cgiar.org (P. Masikati), a.vanrooyen@cgiar.org (A.F. van Rooyen), g.tesfahun@cgiar.org (G.T. Kassie).

\section{Introduction}

Food security for rural households in southern Africa is generally determined in terms of maize production, the region's major staple crop (Grant et al., 2012; Langyintuo et al., 2008; Calcaterra, 2002). Therefore, maize has been identified as one of the key agricultural commodities to enhance food production and food security at continental and sub-regional levels (AU, 2006). Nevertheless, maize yields remain low in many parts of southern Africa (except for 
South Africa), stagnating at around $1 \mathrm{t} /$ ha for the last decade (Smale et al., 2011; Kassie et al., 2012). Past growth in total maize production has been achieved through land expansion instead of crop intensification. However, expansion of agricultural land is increasingly restricted given the reduction of available land and the large resource constraints facing farmers in the region (e.g. labor, capital).

At the same time, increasing importance of livestock as a source of revenue suggests that investments in this sector offer a clear opportunity to improve rural livelihoods and the overall agricultural growth of the region (Chilonda and Minde, 2007; Nin Pratt and Diao, 2008). A promising method of enhancing crop and livestock productivity is increasing the availability and quality of cereal residues as livestock feed (Amede et al., 2009; Alkemade et al., 2012). Feed availability is a major bottleneck for improving livestock production and productivity in the region (associated with animal health, Holness, 1999). This bottleneck can become more severe with the increasing expansion of cropland on communal rangelands, an essential source of livestock feed in the region (De Leeuw, 1997).

Improved dual-purpose maize varieties for food and feed provides a promising technological option to intensify both crop and livestock production by simultaneously increasing the availability and quality of grain production and livestock feed (Berhanu et al., 2012; Blümmel et al., 2012). The potential of these dualpurpose technologies in southern Africa would depend on: the environment, i.e. agro-ecological and socio-economic context of agricultural production (Notenbaert et al., 2012), farm management, i.e. crop-livestock farming systems (Ojiem et al., 2006); and genetics, i.e. quality and quantity of food and feed production of different maize cultivars (Sharma et al., 2010). The objective of this study is to assess the potential of dual-purpose maize on food and feed production and to better target promising cultivars by accounting for the environment, management and genetics on crop-livestock farms in southern Africa. This assessment is a multi-level analysis combining assessments of dual-purpose maize at landscape and farming system levels in mixed croplivestock systems in Malawi, Mozambique and Zimbabwe, as well as including the genetic variability of prominent maize cultivars.

\section{Material and methods}

\subsection{Countries and study sites}

Countries were selected based on secondary data and expert consultation to represent contrasting mixed crop-livestock systems in southern Africa, including sites in Malawi, Zimbabwe and Mozambique (Chilonda et al., 2008).

Farming systems studies were implemented in each of the three countries at selected sites that represent contrasting maizebased systems with different challenges and opportunities for improved dual-purpose maize. The studies were part of the System-wide Livestock Programme (SLP) project on crop residue use, determinants and trade-offs, southern Africa case study (Homann-Kee Tui et al., 2012). Mzimba in northern Malawi has higher rainfall (av. $700-750 \mathrm{~mm}$ per year) and relatively high levels of human populations (57 persons per $\mathrm{km}^{2}$ ) than the other two sites. Agricultural production is more intensified and oriented towards crop production. Nkayi in southwest Zimbabwe and Changara in Central Mozambique have lower rainfall (av. 600-650 $\mathrm{mm}$ persons year) and lower human population densities (23 and 19 persons per $\mathrm{km}^{2}$, respectively); agricultural production is more extensive and livestock is more prominent in agricultural production than in the other site.

\subsection{Analytical approach}

The assessment of the environment, management and genetics of dual-purpose maize integrates three levels of analysis and research outputs that will generate a better understanding of the potential and viability of this technology on improving agricultural production in southern Africa (Fig. 1). These three levels of analysis are:

a. A nested landscape analysis to spatially identify the potential of dual-purpose maize, based on feed biomass production and demand in the three countries (i.e. environment).

b. A farming system analysis to understand and verify the feasibility of the previous spatial analysis based on resource allocation and management in three selected study sites (i.e. management).

c. A maize cultivar analysis to evaluate the potential contribution of different improved dual-purpose maize cultivars in enhancing feed supply (i.e. genetic).

\subsubsection{Landscape analysis}

This nested landscape analysis combines GIS databases to better understand the production and demand for feed in mixed croplivestock systems at a country level. Firstly, data on the distribution of mixed crop-livestock systems is used to identify major areas where dual-purpose varieties could have a niche. Secondly, data on the agro-ecological potential of specific maize cultivars (Maize Mega Environments) is used to better target dual-purpose varieties. Thirdly, Recommendation Domains are used to further stratify the niche of this technology by supply and demand factors. Finally, spatial analyses of rangeland and cropland production are included to quantify the contribution of feed resources. These spatial databases were raster layers with different spatial resolutions (pixel size). To be able to combine them, they were converted to vector data, overlaid and integrated by using Raster to Polygon tool and other Geoprocessing tools in ArcGIS 10. The databases, which are all publicly available, include:

Mixed crop-livestock systems: Distribution of mixed croplivestock systems were defined using the ILRI/FAO global livestock production systems classification (Robinson et al., 2011), based on criteria developed by Thornton et al. (2002) ( $<450$ persons per $\mathrm{km}^{2}$ to differentiate from landless intense systems; $>60$ days LGP and $>20$ persons per $\mathrm{km}^{2}$ to differentiate from livestock-only systems).

Maize Mega Environments: The potential of maize varieties is based on the CIMMYT's Maize Mega Environments (MME; Bellon et al., 2005), developed for matching maize cultivars with climatic key variables such as day length, rainfall precipitation and temperature. These climatic variables were used as layers to stratify by agro-ecological potential (Hartkamp et al., 2000).

Recommendation Domains: Recommendation Domains (RDs) for better targeting of dual-purpose maize cultivars were developed following the approach of Notenbaert et al. (2012) based on three strategic demand and supply criteria: (i) livestock density (here cattle and small ruminants); (ii) human population density; and (iii) feed availability from crop residues of maize, small grains, legumes, sugar cane, roots and tubers. For each of the variables (livestock density, human population density, feed availability), two classes were defined, high $(\mathrm{H})$ and low (L). To separate the two classes, cut off points were defined that represent the averages across mixed farming systems in southern Africa and combining the following data layers: (i) Livestock density of 9 Tropical Livestock Units (TLU) $/ \mathrm{km}^{2}-$ pixel size of $10 \mathrm{~km} \times 10 \mathrm{~km}$ resolution, FAO layers (Wint and Robinson, 2007); (ii) Human population density of $36 \mathrm{PPL} / \mathrm{km}^{2}-$ pixel size of $1 \mathrm{~km} \times 1 \mathrm{~km}$ resolution, using the Global Rural Urban Mapping Project (GRUMP) layers (CIESIN, 2004); (iii) Feed availability of crop residues of $20 \mathrm{t} / \mathrm{km}^{2}-$ pixel 
Sources of data and analysis

Outputs

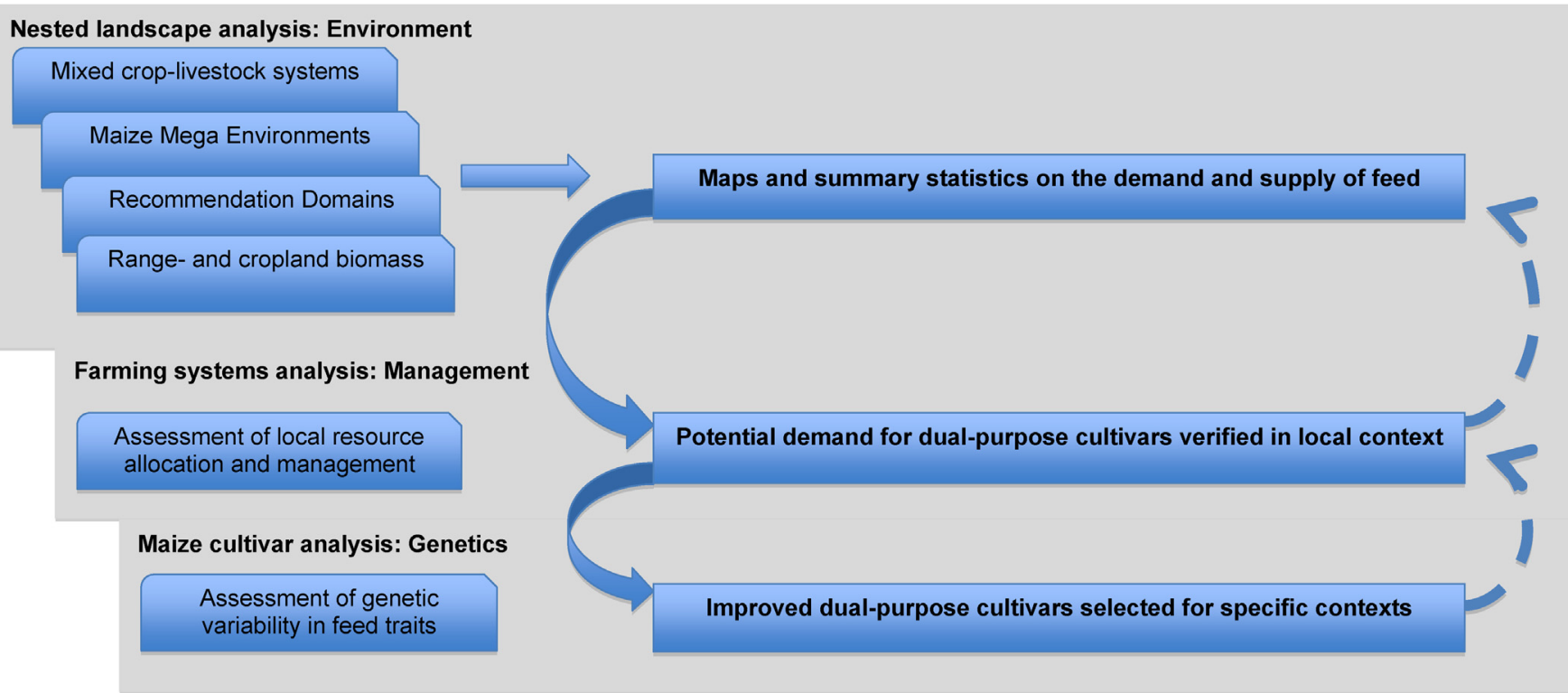

Fig. 1. Schematic diagram of the multi-level research approach used in this study.

size of $10 \mathrm{~km} \times 10 \mathrm{~km}$ resolution, using the Spatial Production Allocation Model (SPAM) layer (SPAM, 2000, v3.0.r6). Total production of all major crops was calculated and weighed by the cropped area.

Range- and cropland biomass: In addition to feed availability from croplands we also assessed the biomass production from rangelands. We assessed the cumulative Net Primary Productivity (NPP) for the years 2000-2011 and then calculated the average annual NPP. The distribution of the NPP was mapped using improved global datasets - pixel size of $1 \mathrm{~km} \times 1 \mathrm{~km}$ resolution, MODIS, developed by Zhao et al. (2005, 2006) and Zhao and Running (2010). Rangelands and cropped areas were differentiated using the dataset developed by Ramankutty et al. (2008) on global pastures and croplands - pixel size of $10 \mathrm{~km} \times 10 \mathrm{~km}$ resolution. The contribution from rangelands relative to croplands was compared based on the area proportion of pastures and croplands, and feed supply from crop residues estimated from the SPAM datasets.

Biomass available from rangelands was estimated using a conservative figure of $30 \%$ of the assessed NPP production (De Leeuw and Tothill, 1990).

Finally, the biomass from rangelands and croplands was related to an upper estimated voluntary feed intake $3 \%$ body weight per TLU, resulting in a maximum total biomass requirement of approximately $2.75 \mathrm{t}$ per TLU and year. Accounting for the intra-annual variability and the spatial distribution of feed quality of croplands and rangelands was beyond the scope of this study. The biomass values present best-possible estimations to inform the spatial stratification and characterization of RDs.

\subsubsection{Farming system analysis}

Based on the landscape analysis, three contrasting sites were selected to better understand how dual-purpose maize could fit different crop-livestock systems. Given the large diversity of agroecologies across the three countries, we opted to combine the landscape analysis with in-depth farming system analysis at sites with different levels of agricultural intensification.

The farming systems analysis in the three selected sites was based on focus group discussions and household level survey conducted with a total of 480 households between 2009 and 2010 (for details see Homann-Kee Tui et al., 2012). For the purpose of this paper we present descriptive statistics that elucidate agricultural/livestock production with emphasis on uses of maize residues.

\subsection{Assessment of a range of maize cultivars from Southern Africa for dual-purpose traits and their potential impact on livestock productivity}

\subsubsection{Residue fodder quality analysis}

Two groups of maize cultivars chosen from CIMMYT maize breeding trials in Zimbabwe previously investigated for residue fodder quantity and quality traits at ILRI, India (Vivek, unpublished) were revisited: (1) advanced hybrids and (2) open-pollinated mostly landraces. Residue samples were analyzed for metabolizable energy (ME) content as described by Ramana Reddy (Ramana Reddy et al., 2013), to estimate the potential of different maize to contribute to the energy requirement of livestock. The statistical differences for the given grain and stover traits between landrace and advanced hybrid maize cultivars were assessed.

\subsubsection{Energy requirements for livestock maintenance and predictions of maize residue intake}

Net energy requirements for maintenance of TLU (250 kg live weight) were calculated as 0.53 $(250 / 1.08)^{0.67}+0.0043 \times 250=21.4 \mathrm{MJ} /$ day according to McDonald et al. (2011). Efficiency of use of metabolizable energy (ME) for maintenance $\left(k_{\mathrm{m}}\right)$ was also calculated according to McDonald et al. (2011) as: $k_{\mathrm{m}}=0.35 q+0.503$ with $q$ the metabolizability calculated as: ME/18.4. Similarly efficiency of ME utilization for live weight gain was calculated as: $k_{1}=0.78 q+0.006$ (McDonald et al., 2011) and the energy content of $1 \mathrm{~kg}$ of live-weight gains was taken as 11.4 MJ (McDonald et al., 2011). Voluntary residue intake (VFI) of a TLU was predicted based on residue ME content based on the equation of Ravi et al. (2013) as: VFI $(\mathrm{kg} / \mathrm{kg} \mathrm{LW})=-3.6+3.52 \mathrm{ME}$ $(\mathrm{MJ} / \mathrm{kg})$.

\section{Results}

\subsection{Landscape analysis}

\subsubsection{Crop-livestock systems and maize potential}

The importance and spatial distribution of mixed crop-livestock systems and areas under maize differs across the three countries (Fig. 2). Mixed crop-livestock systems cover almost $45 \%$ of the total area in Malawi $\left(31,000 \mathrm{~km}^{2}\right), 44 \%$ in Zimbabwe $\left(177,000 \mathrm{~km}^{2}\right)$ 


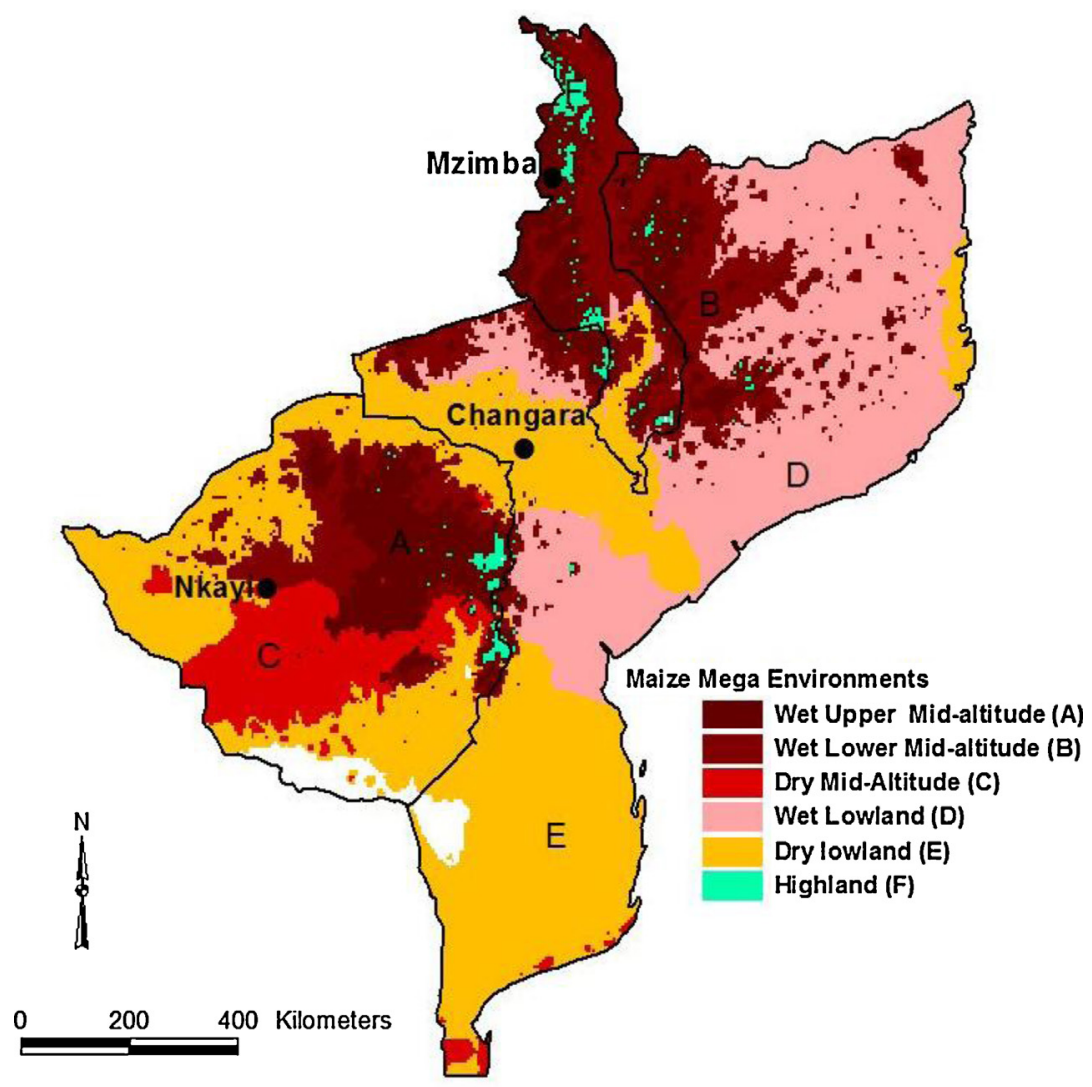

Fig. 2. Maize mega environments across Malawi, Zimbabwe and Mozambique and at the selected field project sites in each country sites. Data source: Hartkamp et al. (2000).

and $21 \%$ in Mozambique $\left(153,000 \mathrm{~km}^{2}\right)$. The maize area within the mixed systems, including range- and cropland, is about $28 \%$ $\left(8600 \mathrm{~km}^{2}\right)$ in Malawi, $8 \%\left(14,636 \mathrm{~km}^{2}\right)$ in Zimbabwe and $2 \%(2707$ $\mathrm{km}^{2}$ ) in Mozambique.

The agro-ecological potential for maize varieties also differs across countries. Malawi has high agro-ecological potential. Although the total area under maize is less, Malawi has the largest maize production of the three countries with currently about 3.3 million tons per annum. The Wet Upper Mid-Altitude maize environment (MME A) covers almost half of the area (48\%). Wet Lower Mid-Altitude (MME B) covers 23\%, Dry Lowland (MME E), covers $18 \%$ and Highland (MME F) covers 11\%. Mzimba, the farming systems study area is located in MME A.

Zimbabwe has lower agro-ecological potential. Despite a larger area under maize, the country produces only about 1.1 million tons of maize per annum. Dry lowlands (MME E) cover 30\% of the area, Wet Upper Mid-Altitude (MME A) covers 26\%, Dry Mid-Altitude (MME C) covers $21 \%$ and Wet Lower Mid-Altitude (ME B) covers $20 \%$. Most of the maize in Zimbabwe is produced in MMEs C (35\%), $\mathrm{A}(26 \%)$ and $\mathrm{E}$ (28\%). It is important to note that the drylands (MME $E$ and $C$ ), which are of relatively low agro-ecological potential for maize production, cover about half of the land in mixed crop systems and produce large quantities of maize. The study area in Nkayi is located in MME C.

In Mozambique land use is comparatively extensive and maize production is only about 0.4 million tons per annum. The country has large agro-ecological areas of high potential with Wet Lowlands (MME D) covering 48\% of the area. Dry Lowlands (MME E, $28 \%$ ) are also common, and smaller areas are with Wet Lower MidAltitude (MME B, 14\%) and Wet Upper Mid-Altitude (MME A, 8\%). Maize coverage is on average only $16 \%$, but in few pockets with maize coverage goes up to $61 \%$. Most maize is produced in MME D
(40\%) and MME A (24\%). The study area in Changara is located in MME E.

\subsubsection{Recommendation domains for improved dual-purpose maize cultivars}

The landscape analysis illustrates that biomass production and demand are also differently distributed across the three countries. Large areas in Malawi show high livestock and human population densities and high cropping densities (Table A.1). High livestock densities are found in $44 \%$ of the area, high human population density in $76 \%$ of the area and high cropping density in $58 \%$ of the area. The most common RDs are LHH (27\%), followed by HHH (19\%), HHL (15\%) and LHL (15\%). Highest demand for dual-purpose maize can be expected in MME A and MME B, which sustains more than 75\% of the country's ruminants and human population. MME A and B also produce more than $70 \%$ of the maize, coverage of cropland with maize is around $50 \%$. In both MEs, RD LHH produces most maize and residue biomass, but livestock population densities are comparatively low, resulting in large potential volumes of maize residue surplus (Tables A.1 and A.2). The study case in Mzimba has high livestock and human population density, and high cropping density (HHH).

In Zimbabwe, human and cropping densities are lower than in Malawi with only $28 \%$ of the land having high human population densities and with only $13 \%$ having high cropping density. In contrast, livestock density in Zimbabwe is high in about $72 \%$ of the country. Most common are RDs HLL covering $43 \%$ of the area followed by LLL (21\%) and HHL (19\%). These RDs fall to a large extent into the dryland areas (MME E and C, with RDs HLL, LLL and HHL each $>20 \%$ ). Traditionally rangelands sustained livestock production in these areas; with cropland expansion there is now an important gap to supplement livestock nutrition. Nkayi represents 


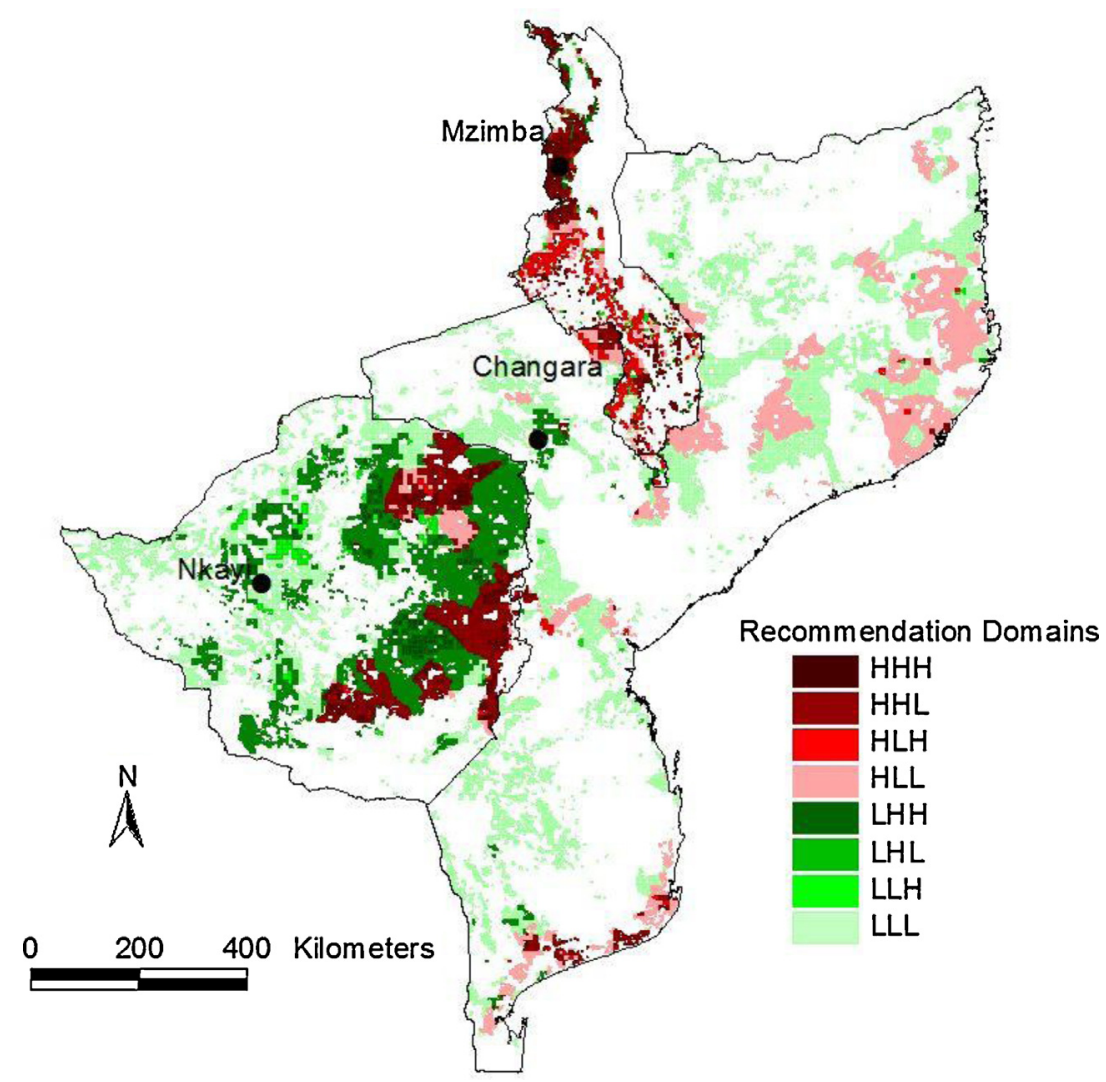

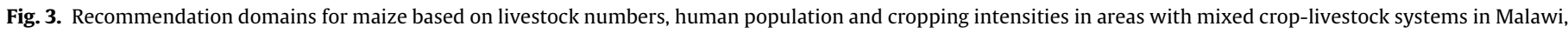

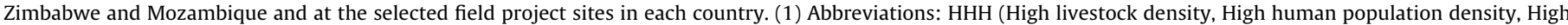

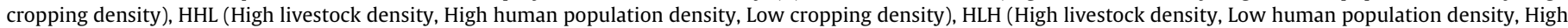

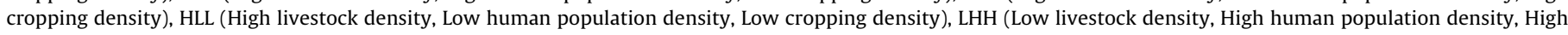

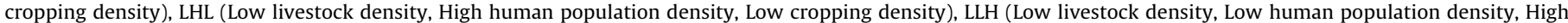

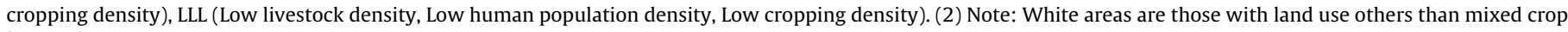
livestock systems.

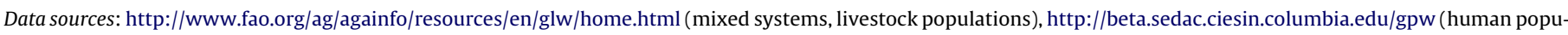
lations); http://mapspam.info/2012/01/spam2000v3-0-6 (crop production).

a dryland area (MME C), even though with low livestock and low human population densities and low cropping density (LLL).

In Mozambique, only $5 \%$ of the land has high livestock density whereas high human population and $2 \%$ of the land by high cropping density characterize $41 \%$ of the land. The wet and dry lowlands (ME D and E) seem to have a comparatively greater potential for dual-purpose maize, since more than $70 \%$ of the country's livestock are found here. They cover $73 \%$ of the area with mixed crop-livestock systems and about two-thirds of the country's maize is grown there. The largest RDs are LLL (56\%) and LHL (37\%), and cover large parts of MME D and E. Like in Zimbabwe, there could be a demand for maize residues if other feeds are not available. Changara represents such an important livestock area in MME E and in RD LLL.

\subsubsection{Rangeland and cropland biomass}

The analysis of biomass production on range- and croplands illustrates lowest total NPP in southern Zimbabwe and Mozambique and an increase in northern direction (Fig. 3). As expected, NPP is higher in Malawi compared to Zimbabwe and Mozambique. Due to larger area share, however, the rangelands produce more biomass in Mozambique and Zimbabwe (17.8 and 7.5 Mio t, respectively) as compared to Malawi (1.0 Mio t). Part of this biomass can be used for livestock feeding (Table 1).

At the study sites, the NPP assessment confirms higher total biomass (crop and rangelands) in Mzimba, Malawi (7.4t/ha), as compared to Changara, Mozambique, and Nkayi, Zimbabwe (6.2 t/ha and 5.3t/ha, respectively, Fig. 4). In terms of biomass available to feed livestock, Mzimba has more crop residues as compared to Nkayi and Changara (0.6 t/ha, $0.3 \mathrm{t} / \mathrm{ha}, 0.2 \mathrm{t} / \mathrm{ha}$, respectively). The biomass from rangelands is however higher in Changara and Nkayi as compared to Mzimba (0.8t/ha, 0.6t/ha, $0.3 \mathrm{t} / \mathrm{ha}$, respectively), owing to the higher percentages of rangelands as indicated by Ramankutty et al. (2008). However, in Changara and Nkayi the inter-annual variability is also higher as compared to Mzimba, illustrating higher risk in production and feed availability (Fig. 5).

Comparison of the potential biomass production from rangelands and croplands in relation to the estimated livestock feed demand is summarized in Table 1; Table A.2 provides a more detailed overview on the potential biomass availability per livestock unit in RDs and MMEs. Accordingly, Mozambique, Zimbabwe and Malawi produce around 18.9, 9.8 and 3.1 Mio tons of biomass from rangeland and croplands for potential livestock feeding, respectively (Table 1 ). In relation to the estimated livestock units, however, Malawi has on average more feed available (9.7t/TLU) than Mozambique (7.3t/TLU) and Zimbabwe (4.4t/TLU). Across countries, biomass seems at surplus, especially in Malawi and Mozambique. As Table A.2 column B/U illustrates, biomass surplus in relation to potential livestock voluntary feed intake is found especially in RDs with low livestock density and high or low 
Table 1

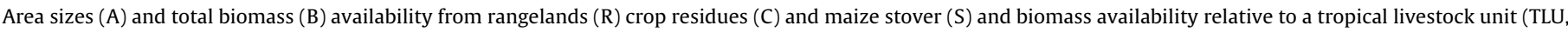
$\mathrm{U})$ for Recommendation Domains in Malawi, Zimbabwe and Mozambique.

\begin{tabular}{|c|c|c|c|c|c|c|c|c|c|c|c|c|c|c|c|c|c|c|c|c|c|}
\hline \multirow[t]{3}{*}{$\mathrm{RDs}^{\mathrm{a}}$} & \multicolumn{7}{|l|}{ Malawi } & \multicolumn{7}{|c|}{ Zimbabwe } & \multicolumn{7}{|c|}{ Mozambique } \\
\hline & A & $\mathrm{R}$ & $\mathrm{C}$ & $\mathrm{S}$ & $\mathrm{C}: \mathrm{B}$ & $\mathrm{S}: \mathrm{C}$ & $\mathrm{B} / \mathrm{U}$ & A & $\mathrm{R}$ & C & $\mathrm{S}$ & $\mathrm{C}: \mathrm{B}$ & $\mathrm{S}: \mathrm{C}$ & $\mathrm{B} / \mathrm{U}$ & A & $\mathrm{R}$ & $\mathrm{C}$ & $\mathrm{S}$ & $C: B$ & $S: C$ & $\mathrm{~B} / \mathrm{U}$ \\
\hline & ‘000 km² & '000t & & & $\%$ & & $\mathrm{t}$ & ‘000 km² & ‘000t & & & $\%$ & ‘ & $\mathrm{t}$ & $000 \mathrm{~km}^{2}$ & ‘000t & & & $\%$ & & $\mathrm{t}$ \\
\hline $\mathrm{HHH}$ & 6 & 151 & 587 & 162 & 80 & 28 & 9 & 7.9 & 351 & 364 & 198 & 51 & 54 & 6 & 0.5 & 22 & 83 & 12 & 79 & 14 & 20 \\
\hline HHL & 4.6 & 114 & 37 & 13 & 25 & 35 & 2 & 34.5 & 1260 & 234 & 118 & 16 & 50 & 3 & 4.3 & 283 & 41 & 20 & 13 & 49 & 5 \\
\hline HLH & 1.6 & 69 & 114 & 39 & 62 & 34 & 6 & 9.8 & 460 & 880 & 349 & 66 & 40 & 9 & 0 & 3 & 8 & 0 & 73 & 0 & 9 \\
\hline HLL & 1.3 & 42 & 6 & 2 & 13 & 33 & 2 & 75.9 & 2924 & 295 & 211 & 9 & 72 & 3 & 3.2 & 261 & 17 & 6 & 6 & 35 & 6 \\
\hline LHH & 8 & 337 & 1127 & 204 & 77 & 18 & 26 & 0.9 & 59 & 45 & 6 & 43 & 13 & 14 & 1.9 & 158 & 102 & 37 & 39 & 36 & 24 \\
\hline LHL & 4.6 & 129 & 38 & 16 & 23 & 42 & 6 & 5.6 & 389 & 40 & 11 & 9 & 28 & 13 & 56.4 & 5902 & 367 & 129 & 6 & 35 & 42 \\
\hline LLH & 2.1 & 117 & 216 & 70 & 65 & 32 & 28 & 5.1 & 298 & 236 & 84 & 44 & 36 & 15 & 0.9 & 77 & 61 & 11 & 44 & 18 & 81 \\
\hline LLL & 2.5 & 68 & 11 & 5 & 14 & 45 & 6 & 36.8 & 1727 & 212 & 124 & 11 & 58 & 9 & 85.9 & 11,061 & 491 & 215 & 4 & 44 & 79 \\
\hline TOTAL & 30.7 & 1027 & 2136 & 511 & 68 & 24 & 10 & 176.5 & 7468 & 2306 & 1101 & 24 & 48 & 4 & 153.1 & 17,767 & 1170 & 430 & 6 & 37 & 7 \\
\hline
\end{tabular}

a Abbreviations: HHH (High livestock density, High human population density, High cropping density), HHL (High livestock density, High human population density, Low

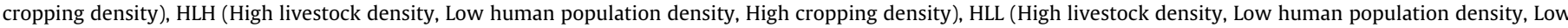

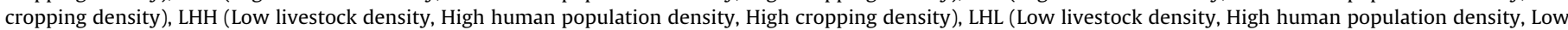

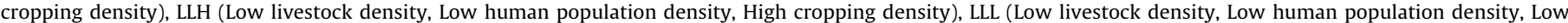
cropping density).

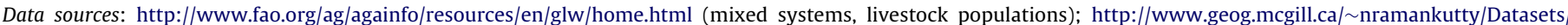
Datasets.html (rangelands, cropland); http://sedac.ciesin.columbia.edu/gpw (NPP); http://mapspam.info/2012/01/spam2000v3-0-6 (crop production).

cropping density (LHH, LLH, LLL), against biomass deficits in RDs with high livestock density and low cropping density (RDs HLL and HHL).

Out of the potential biomass available for livestock, Malawi produces 2.1 Miot biomass from croplands and about $1.0 \mathrm{Miot}$ biomass from rangelands, the greatest proportion from croplands in the cross-country comparison (Table 1 ). Maize residues supply between 1.3 and $5.8 \mathrm{t}$ residue biomass per TLU. Potential biomass surplus is substantial at sites with high cropping density and low livestock density. Potential feed deficits were in RDs HHL ( $1 \mathrm{t} / \mathrm{TLU})$ and HLL ( $2 \mathrm{t} / \mathrm{TLU})$, where livestock density is high against low cropping density.

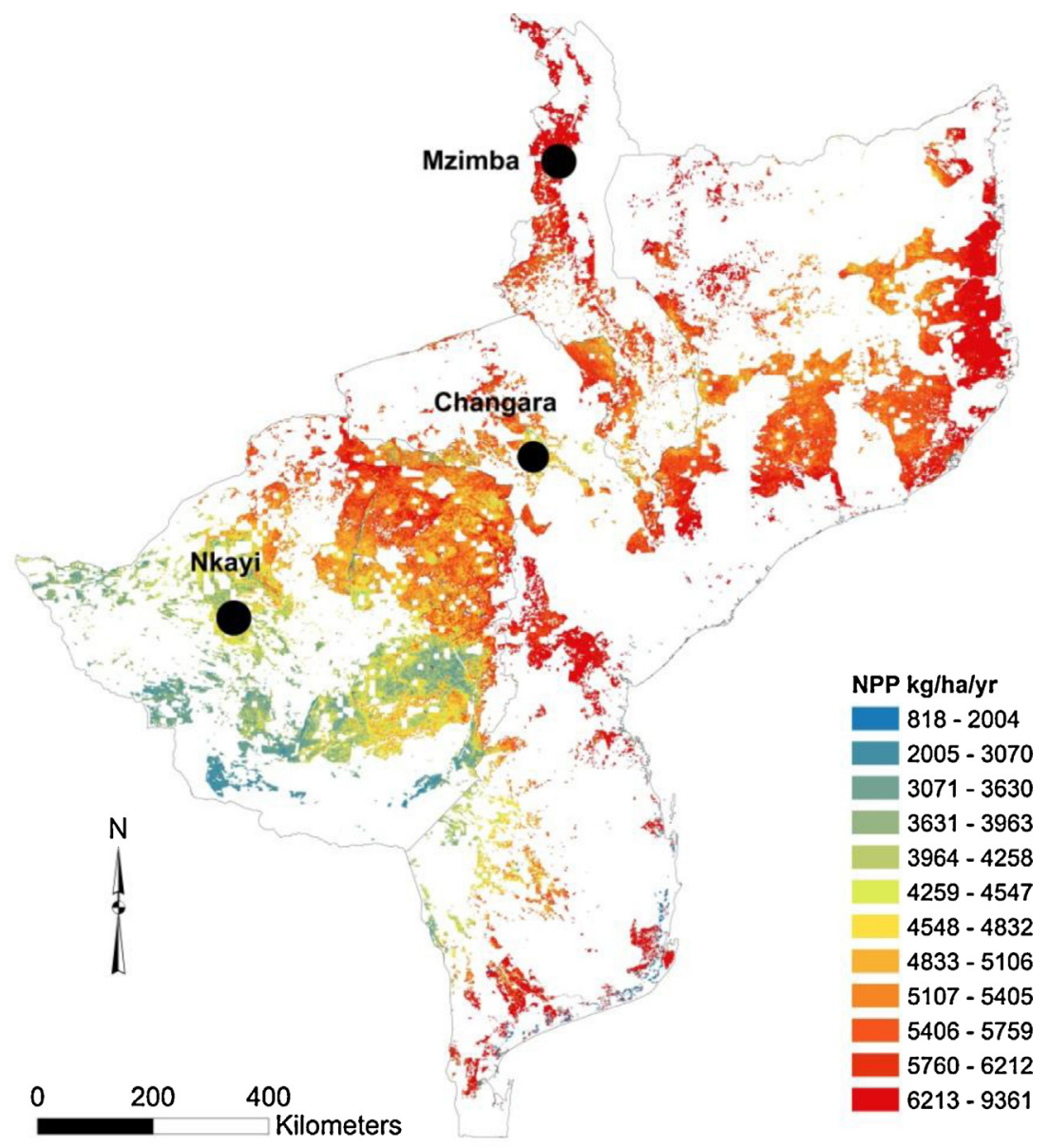

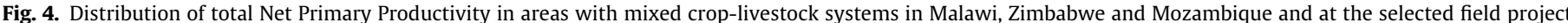
sites in each country. (1) Abbreviations: NPP (Net Primary Productivity). (2) Note: White areas are those with land use others than mixed crop-livestock systems. Data sources: http://www.fao.org/ag/againfo/resources/en/glw/home.html (mixed systems); http://sedac.ciesin.columbia.edu/gpw (NPP). 


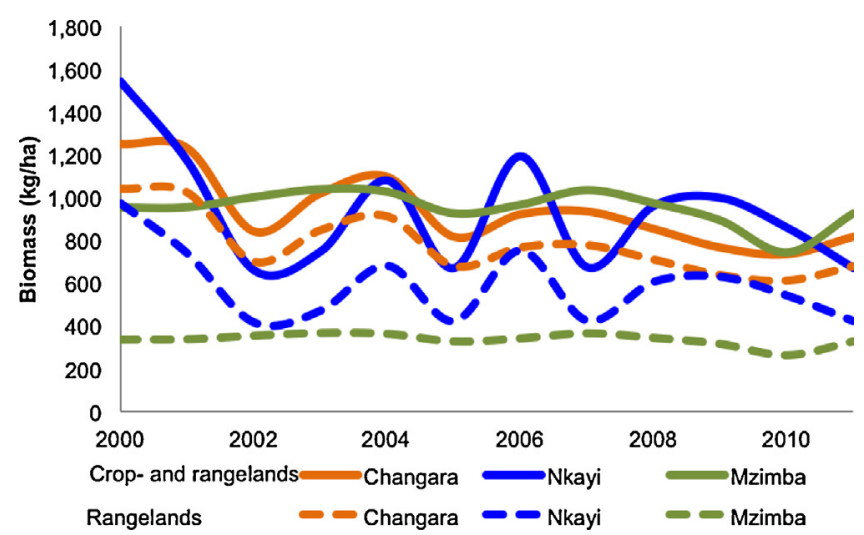

Fig. 5. Annual biomass production from crop and rangelands at the selected field project sites in each country.

Data sources: http://www.fao.org/ag/againfo/resources/en/glw/home.html (mixed systems); $\quad$ http://www.geog.mcgill.ca/ nramankutty/Datasets/Datasets.html (rangelands, croplands), http://sedac.ciesin.columbia.edu/gpw (NPP).

In Zimbabwe the rangelands produce substantially more biomass to feed livestock (7.5 Miot) and croplands produce less (2.3 Mio t). In recommendation domains with high cropping density crop residues contribute between 43 and 66\% to total biomass. The contribution of maize residues to crop residues varies between 13 and $54 \%$ and maize residues supply between 0.8 and $2.4 \mathrm{t}$ biomass per TLU. Maize residues dominate and contribute up to $72 \%$ to crop residue biomass, but only between 0.2 and $0.6 \mathrm{t}$ biomass per TLU.

Like Zimbabwe, rangelands in Mozambique (17.8 Miot) produce more biomass in comparison to crop residues (1.2 Miot). Crop residues contribute between 39 and $79 \%$ to the biomass in the areas with high cropping density, and less than $15 \%$ in areas with low crop intensity. Up to $50 \%$ of the crop residue biomass stems from maize residues; relatively high proportions are found in areas with high as well as low cropping density.

\subsection{Farming system analysis}

The study sites fall in RDs with different levels of intensification and management and this is expected to influence the demand for maize residues as feed. Mzimba in Malawi is in an area with high agro-ecological potential (MME A) and in RD HHH, with high predicted feed demand by livestock and high levels of biomass production. We expected to find highly integrated crop-livestock production, and high demand for maize residues as incentive for adopting dual-purpose maize. Nkayi in Zimbabwe and Changara in Mozambique, both are in areas with lower agro-ecological potential, and in RD LLL, relatively extensive systems with high risks in production and livestock more important. Table 2 presents management characteristics for the different farming systems.

In Mzimba all households produce maize, but the average cultivated land per household is small ( $<1 \mathrm{ha}$ ). In contrast, only slightly more than $50 \%$ of the households have livestock and herd sizes are rather small. For maize production, farmers invest in high rates of inorganic fertilizer $(>100 \mathrm{~kg} / \mathrm{ha})$ and almost half of the farmers use improved seeds. They attain relatively high maize yields, around $1.5 \mathrm{t} / \mathrm{ha}$, and are able to sell some surplus maize. Daily milk yields at about 11 per cow are low and cattle losses through mortalities are three times higher than consumptive off-takes. Despite high livestock densities at landscape level and the estimated biomass production from maize residues being also relatively high (1.9 t/ha; $1.2 \mathrm{t} / \mathrm{TLU})$, farmers make relatively limited use of maize residues as livestock feed. Farmers in Mzimba have excess maize residues and also lack awareness on improved uses of maize residues. Feed quantity seems not to be a limiting factor to improve livestock production. Feed quality is the most limiting factor.

In Nkayi close to $100 \%$ of the household engage in maize production with maize fields per household almost twice the size of those in Mzimba. Average maize yields are less than $1 \mathrm{t} / \mathrm{ha}$. Inorganic fertilizer application is low $(<10 \mathrm{~kg} / \mathrm{ha})$, still many households use improved seeds. About three quarters of the households keep livestock with average herd sizes of 3.9TLU. These farmers make greater use of the livestock functions and also support crop production. Cattle productivity is however low as reflected in high mortality rates around 15\%, against a consumptive off-take of less than $2 \%$; milk yields are also low. Dry season feed shortages are pronounced. Fewer crop residues are available than in Malawi, about $1.2 \mathrm{t} / \mathrm{ha}$ and only $0.3 \mathrm{t} / \mathrm{TLU}$. Farmers estimated that crop residues contribute about $40 \%$ of livestock feed intake during the dry season. Apart from cattle grazing residues in situ (60\%), farmers have started to collect and store maize residues. They feed about $20 \%$ of the maize residues to livestock at the kraal during the dry season. Fodder technologies are not common.

In Changara, less than half of the households produce maize. Only about a third of the households keep livestock, and herd sizes of those with livestock are comparatively large (5.5TLU). Average maize yields are extremely low $(<400 \mathrm{~kg} / \mathrm{ha})$. Livestock off-takes above $10 \%$ confirm the important role of livestock for cash income. Farmers also indicate severe feed shortages during the dry season. Cropping density is less as compared to Malawi and Zimbabwe, and more rangeland biomass is available. Livestock feed to about $75 \%$ on rangelands during the dry season. Maize residue production at about $0.6 \mathrm{t} /$ ha provides less than $0.1 \mathrm{t}$ of residues per TLU. These residues are largely grazed in situ.

\subsection{Cultivar analysis}

This section looks at genetic variations of maize cultivars in grain and residue quantity and residue fodder quality as reflected by ME content to explore the potential of improving feed resources with dual-purpose maize cultivars. Feed resources can be improved by increasing quantity and quality. However, the former is only useful when livestock consumes the additional biomass, i.e. voluntary feed intake can respond, which depends on quality aspects of the additional feed resource.

\subsubsection{Variability in maize cultivars for grain and residue yield and residue fodder quality}

Variations in grain and residue yields and residue fodder ME that CIMMYT Southern Africa has been targeting for higher potential areas (advanced hybrids) and for lower potential areas (landraces) are presented in Table 3. Major differences between landraces and advanced hybrids were in grain yields and corresponding harvest index (HI), which was 0.35 and 0.42 in landraces and advanced hybrids, respectively. Cultivar-dependent variations were substantial in ME yield per ha - the product of residue yield and residue ME content - where ME yields per ha varied 5.7-fold and 2.3-fold in landraces and hybrids, respectively, largely as a result in variations in residue yields. Still, residue ME content varied by about $1 \mathrm{MJ} / \mathrm{kg}$ in landraces and by $0.74 \mathrm{MJ} / \mathrm{kg}$ in hybrids. There was no significant $(P>0.05)$ relationship between residue fodder ME and grain yields.

\section{Discussion}

\subsection{Multi-level landscape analysis to better assess the potential for dual-purpose maize}

A nested and spatial explicit landscape analysis complemented by a farming system analysis allows a better assessment of the potential for dual-purpose maize in southern Africa. The landscape 
Table 2

Selected indicators for maize and cattle production at the field project sites in each country.

\begin{tabular}{|c|c|c|c|c|c|c|c|}
\hline & \multirow[t]{2}{*}{ Units } & \multicolumn{2}{|c|}{ Mzimba } & \multicolumn{2}{|l|}{ Nkayi } & \multicolumn{2}{|c|}{ Changara } \\
\hline & & Mean & SD & Mean & SD & Mean & SD \\
\hline \multicolumn{8}{|c|}{ Cropland, maize grain and residue production } \\
\hline Total cropland & ha/HH & 1.3 & 1 & 1.9 & 1.3 & 1.5 & 1.1 \\
\hline HH with maize & $\% \mathrm{HH}$ & 100 & & 99.4 & & 41.3 & \\
\hline Maize fields & ha/HH & 0.8 & 0.5 & 1.4 & 1.1 & 0.7 & 0.6 \\
\hline \multicolumn{8}{|c|}{ Maize cropping pattern } \\
\hline Fertilizer & $\mathrm{kg} / \mathrm{ha}$ & 117.9 & 60.9 & 9.7 & 29.3 & 0 & 0 \\
\hline Org. manure & $\mathrm{kg} / \mathrm{ha}$ & 63.4 & 149.6 & 479.3 & 1170.3 & 0 & 0 \\
\hline Hybrid seed & $\% \mathrm{HH}$ & 42.5 & & 41.5 & & 13.6 & \\
\hline Draft power & $\% \mathrm{HH}$ & 3.8 & & 96.2 & & 50 & \\
\hline Grain yields & $\mathrm{kg} / \mathrm{ha}$ & 1595.6 & 1141.7 & 756.3 & 858.0 & 364.8 & 235.3 \\
\hline Proportion sold & $\%$ & 10.2 & 14.4 & 6.7 & 13.7 & 2.1 & 7.8 \\
\hline \multirow[t]{2}{*}{ Residue availability } & $\mathrm{kg} / \mathrm{ha}$ & 1882.9 & 1225.3 & 1248.2 & 956.2 & 661.4 & 349.0 \\
\hline & $\mathrm{kg} / \mathrm{TLU}^{2}$ & 1205.0 & & 327.5 & & 79.5 & \\
\hline \multicolumn{8}{|l|}{ Residue uses } \\
\hline Grazing livestock & $\%$ & 55.5 & 31.1 & 64.8 & 33.4 & 76.5 & 34.7 \\
\hline Mulching & $\%$ & 19.2 & 27.9 & 6.7 & 17.6 & 8.8 & 6.6 \\
\hline Burnt & $\%$ & 17.9 & 27 & 2.7 & 12.2 & 7.3 & 15.4 \\
\hline Kraal feeding & $\%$ & 1.1 & 8.1 & 20.3 & 28.1 & 3.6 & 16.6 \\
\hline \multicolumn{8}{|c|}{ Herd ownership and cattle production } \\
\hline HH with ruminants & $\% \mathrm{HH}$ & 53.1 & & 74.4 & & 34.4 & \\
\hline Herd sizes & TLU/HH & 1.8 & 3.4 & 3.9 & 5.6 & 5.5 & 7.3 \\
\hline \multicolumn{8}{|l|}{ Dry season feeding } \\
\hline Rangelands & $\%$ & 60.3 & 22.1 & 61.1 & 24.3 & 75.4 & 11.3 \\
\hline CR grazed in situ & $\%$ & 24.6 & 22.5 & 15.7 & 20.3 & 22.3 & 11 \\
\hline CR collected and fed & & 12.1 & 22.4 & 23.3 & 24.7 & 2.3 & 5.7 \\
\hline \multicolumn{8}{|l|}{ Herd dynamics } \\
\hline Mortality & $\%$ & 9.7 & 20.1 & 14.6 & 19.3 & 12.9 & 19.5 \\
\hline Sales & $\%$ & 0 & 0 & 0.4 & 2.7 & 12.6 & 16.3 \\
\hline Consumption & $\%$ & 2.9 & 7.3 & 1.1 & 3.8 & 0 & 0 \\
\hline Milk yields & 1/day & 1.3 & 0.6 & 1.3 & 0.6 & 1.5 & 0.7 \\
\hline
\end{tabular}

(1) Total kg residues per total TLU. (2) Abbreviations: HH (household), CR (crop residues).

Data source: Homann-Kee Tui et al. (2012).

analysis confirms the results of Notenbaert et al. (2012), specifically: (i) there is a promising niche for dual-purpose maize to increase feed availability in large areas of the selected countries and (ii) there is a high spatial variability in the demand for and supply of maize residues, across and within the selected countries in southern Africa, reflecting that the potential for dual-purpose maize is heterogeneous. The spatial variability illustrated by the present study substantiates the need for better targeting maize development interventions in southern Africa (Williams, 1994; Omamo et al., 2006; Pender et al., 2006). Dual-purpose maize can be targeted to areas with higher level of agricultural intensification and crop-livestock integration (half of the land with mixed crop-livestock systems in Malawi, parts of northeast Zimbabwe, and few areas in Mozambique) and more dry and lowland areas with extensive agriculture but large populations of livestock (half of Zimbabwe and Mozambique).

The present study modified the methodology of Notenbaert et al. (2012) by assessing the contribution of rangeland to feed resources since rangelands provide a large share of the feed resources in southern Africa. Including rangelands in the analysis could suggest

Table 3

Grain and stover traits in advanced maize hybrids and in maize landraces from Zimbabwe.

\begin{tabular}{|c|c|c|c|c|}
\hline Trait & Units & Mean & Range & $P>F$ \\
\hline \multicolumn{5}{|l|}{ Landrace cultivars $(n=14)$} \\
\hline Grain yield $^{-1}$ & (kg/ha) & 1442 & $192-3186$ & 0.002 \\
\hline Stover yield & (kg/ha) & 2660 & $1267-6167$ & 0.0001 \\
\hline Nitrogen & $(\%)$ & 0.64 & $0.51-0.86$ & 0.01 \\
\hline Neutral detergent fiber & $(\%)$ & 76.6 & $72.9-79.3$ & 0.02 \\
\hline In vitro digestibility & $(\%)$ & 48.0 & $44.5-50.4$ & 0.01 \\
\hline Metabolizable energy & $(\mathrm{MJ} / \mathrm{kg})$ & 7.00 & $6.40-7.43$ & 0.02 \\
\hline Metabolizable energy yield & (MJ/ha) & 17,102 & $7290-41,725$ & 0.0001 \\
\hline \multicolumn{5}{|c|}{ Advanced hybrid cultivars $(n=15)$} \\
\hline Grain yield ${ }^{\mathrm{a}}$ & $(\mathrm{kg} / \mathrm{ha})^{-}$ & 2259 & $1309-3837$ & 0.51 \\
\hline Stover yield & (kg/ha) & 3070 & $2250-4667$ & 0.0007 \\
\hline Nitrogen & $(\%)$ & 0.53 & $0.41-0.65$ & 0.27 \\
\hline Neutral detergent fiber & $(\%)$ & 75.9 & $73.8-77.7$ & 0.40 \\
\hline In vitro digestibility & $(\%)$ & 47.8 & $46.3-50.5$ & 0.03 \\
\hline Metabolizable energy & $(\mathrm{MJ} / \mathrm{kg})$ & 6.95 & $6.60-7.34$ & 0.08 \\
\hline Metabolizable energy yield & (MJ/ha) & 20,503 & $14,308-32,293$ & 0.0003 \\
\hline
\end{tabular}

Data source: CIMMYT Southern Africa trials (Vivek, unpublished). $P>F$ values indicate statistical differences/no differences for given traits between cultivars.

a Only two field replications available. 


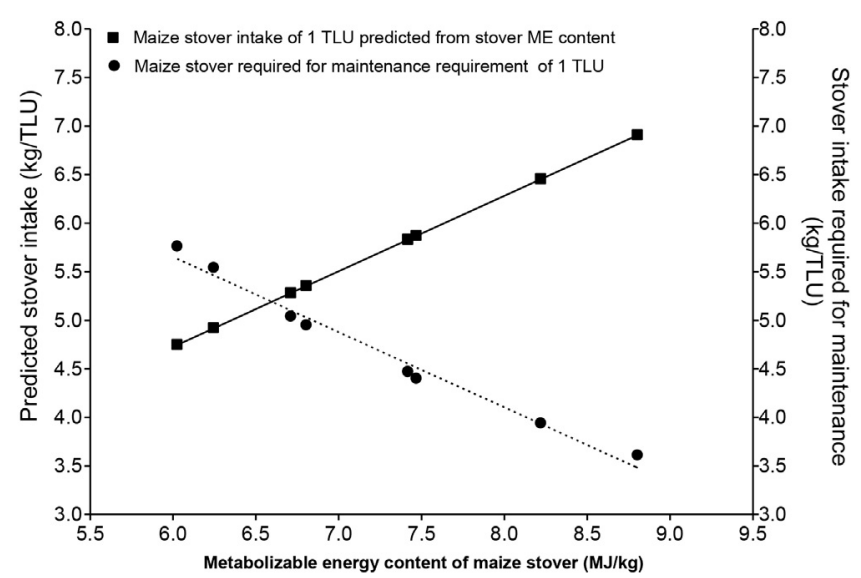

Fig. 6. Relationships between maize stover metabolizable energy content and voluntary stover intake and stover requirements to provide for maintenance requirements per TLU (Tropical Livestock Unit). Stover intake was predicted from the relationships described by Ravi et al. (2013).

large surplus of biomass relative to TLU, notably in the extensively used RDs (Table 1). However, much of this biomass from rangelands might actually be of limited use since seasonal variability in its feed quality results in a decline in ME (Bredon et al., 1987) and protein digestibility (Holness, 1999), which restricts livestock voluntary feed intake (see also discussion below on maize stover intake in Section 4.2). In addition, water constraints and limited rangeland management, reported during focus group discussions at the sites, might restrict livestock from moving to areas with available feed resources (Homann-Kee Tui et al., 2012). Feed markets, that could also play a buffering role in times of feed deficits, are developed in the commercial farming sector, but are of far distance and difficult to access for most smallholder farmers. Under such conditions, dual-purpose maize residues can still make an important contribution to livestock feeding, specifically when the quality of the maize residue is superior to the fodder quality from rangelands (Section 4.2).

The landscape approach adapted in this paper can help to identify socio-ecological niches for technologies to improve feed quality and quantity, specifically dual-purpose maize varieties (Ojiem et al., 2006). Areas where investments in feed quality improvements are likely to pay off, and those that are prone to face greater feed deficits can be identified. This needs to be combined with more process oriented research and further contextualization of the trajectories for agricultural development (i.e. participatory discourse with farmers, multi-stakeholder forums) to verify the real bottlenecks and opportunities that would influence the potential for specific dual-purpose maize varieties. Specific maize cultivars (quality/quantity) can then be targeted to RDs with different biomass demand and availability, having also considered supply from rangelands. This multi-level landscape approach is exemplified in Fig. 1 and can help to scale out dual-purpose crop technologies.

\subsection{Opportunities and limitations for improving feed resources in Zimbabwe, Malawi and Mozambique through choice of maize cultivars}

Dual-purpose maize cultivars can mitigate feed shortages by increasing the available feed quantity. However, it is important to realize that increasing maize residue quantity will have impact only if the residue availability is below the level of voluntary feed intake of livestock for feed stuff of a given quality. Livestock respond to increasing biomass feed quality with increasing voluntary feed intake (Van Soest, 1994). These relations are exemplified in Fig. 6 using regression equations from Ravi et al. (2013) that related maize residue ME content to residue intake per TLU (Fig. 6 solid line and square symbols). In addition, Fig. 6 shows the amount of maize residue intake required to meet the maintenance requirements of a TLU (equation from McDonald et al., 2011). At a maize residue ME content of about $6 \mathrm{MJ} / \mathrm{kg}$ VFI of a TLU would be about $4.7 \mathrm{~kg} /$ day (solid line, full square) whereas about $5.7 \mathrm{~kg} /$ day would be needed to provide for the TLU maintenance requirement (dashed line, full circles). Increasing residue quantity under this condition would only be useful if actual intake is below $4.7 \mathrm{~kg}$ (or more generally below the intakes indicated by the solid line). Otherwise only cultivars with higher residue quality would help the TLU to get closer to meeting its maintenance requirement or provide sufficient ME for live weight gain and/or milk production (intersect of solid and dashed line at about 6.6 MJ ME/ $\mathrm{kg}$ ). In both maize landraces and hybrids, residue $\mathrm{ME}$ at the higher end of the quality range (i.e. $\geq 7.34 \mathrm{MJ} \mathrm{ME} / \mathrm{kg}$, Table 3) would provide sufficient energy for the maintenance requirement and provide sufficient ME for about $200 \mathrm{~g}$ of live weight gain, assuming an energy content of liveweight gain of $11.4 \mathrm{MJ} / \mathrm{kg}$. However, none of these landraces and advanced hybrids were specifically investigated for dual-purpose traits before the current one time spot-on analysis (Vivek, personal communication). Exploitable variations in maize residue traits will likely be greater after inclusion of phenotyping for maize stover quality in the investigation of larger germplasm pools. For example Zaidi et al. (2012) report ranges in maize residue ME in hybrids of 6.67-8.17 MJ/kg for South Asia and Berhanu et al. (2013) reported mean ranges of 7.8-9.2 $\mathrm{MJ} \mathrm{ME} / \mathrm{kg}$ in maize hybrids tested across multi-locations in Ethiopia. Thus dual-purpose maize cultivars with superior residue fodder quality compared to currently available cultivars might soon be available in Southern Africa.

Relating above considerations to the means and ranges in maize residue qualities in CIMMYT landraces and hybrids (Table 3) it can be calculated that, depending on maize residue ME content, $4.47 \mathrm{~kg}-5.36 \mathrm{~kg}$ would be required per day and $1632-1956 \mathrm{~kg}$ per year to provide the maintenance requirement for $1 \mathrm{TLU}$, see Table 4 . This amount is far more than the total maize residue availability per TLU at Mzimba, Nkayi or Changara, which was of 1205, 328 and $80 \mathrm{~kg} / \mathrm{TLU}$, respectively (Table 2). However, maize residues will be particularly important as dry season feed for about 3 months with a requirement of approximately $400-500 \mathrm{~kg}$ of maize residue per TLU. These considerations suggest that improved maize residue fodder quality will be more relevant in sites such as Mzimba whereas maize residue quantity might take precedence over quality in sites such as Nkayi and Changara. However, in all sites, farmers' decisions about use of maize residues as fodder will be affected by the availability and the quality of biomass from rangelands. However, given the fact however that farmers at the sites often sold livestock to buy food when crop harvests were insufficient, boosting maize yields still seems to be a good option, best through a combination of improved crop management and technologies for enhancing crop-livestock integration, including dual-purpose crops of higher biomass and feed value. Dual-purpose maize can contribute to such positive feedbacks loops (ICRISAT, 2012).

\subsection{Pressures and trade-offs in space}

The spatial variability in feed supply and demand implies different pressures and trade-offs in maize residue uses across countries and sites. Livestock feed is a major use of maize residues in mixed crop-livestock systems (Valbuena et al., 2012). Therefore, when looking at other uses of residues (e.g. soil mulch, household fuel and construction), pressures and trade-offs for using maize residues are high in areas where livestock is an important livelihood activity and alternative resources are not available or affordable. This study indicates potential high pressures and trade-offs in maize residue 
Table 4

Daily and yearly requirements of maize stover for the provision of the energy maintenance requirements in maize landraces and hybrid cultivars of different qualities.

\begin{tabular}{|c|c|c|c|c|c|c|c|}
\hline & \multirow[t]{2}{*}{ Units } & \multicolumn{3}{|c|}{ Landraces } & \multicolumn{3}{|c|}{ Advanced hybrids } \\
\hline & & $\mathrm{ME}_{\text {Mean }}$ & $\mathrm{ME}_{\mathrm{Min}}$ & $\mathrm{ME}_{\mathrm{Max}}$ & $\mathrm{ME}_{\text {Mean }}$ & $\mathrm{ME}_{\mathrm{Min}}$ & $\mathrm{ME}_{\mathrm{Max}}$ \\
\hline Stover ME content & $(\mathrm{MJ} / \mathrm{kg})$ & 7.0 & 6.40 & 7.43 & 6.95 & 6.60 & 7.34 \\
\hline Stover intake required for maintenance & $(\mathrm{kg} / \mathrm{d} / \mathrm{TLU})$ & 4.81 & 5.36 & 4.47 & 4.85 & 5.16 & 4.54 \\
\hline Stover intake required for maintenance & $(\mathrm{kg} / \mathrm{y} / \mathrm{TLU})$ & 1756 & 1956 & 1632 & 1767 & 1883 & 1657 \\
\hline Stover intake predicted by ME content & $(\mathrm{kg} / \mathrm{d} / \mathrm{TLU})$ & 5.26 & 4.73 & 5.64 & 5.22 & 4.91 & 5.56 \\
\hline Stover required per year at predicted intake & $(\mathrm{kg} / \mathrm{y} / \mathrm{TLU})$ & 1920 & 1726 & 2059 & 1905 & 1792 & 2029 \\
\hline
\end{tabular}

Data source: CIMMYT Southern Africa trials; own calculations.

use in Nkayi (Zimbabwe) and Changara (Mozambique) as a result of the livestock population, the low productivity of rangelands and limited investments in fodder technologies, particularly at the end of the long dry season. Even though the amount of biomass from crop residues is also low, farmers rely mainly on these residues to feed livestock during that specific period. Potential pressures and trade-offs in maize residue uses are relatively low in areas with high biomass production, despite relatively high livestock densities, e.g. Mzimba (Malawi).

Promising options to alleviate potential pressures and tradeoffs depends on the factors and processes at different scales. For instance, the increasing growth of the demand for livestock products in southern Africa (i.e. beef and milk) represent a clear opportunity to intensify crop-livestock production and enhance the livelihood of poor households (Delgado et al., 1999; World Bank et al., 2013). If governments were to capitalize on local production systems and link farmers to trade to these markets, this will require more feed, increasing the trade-offs (Baltenweck et al., 2003). On the supply side, the expansion of croplands of low productivity into rangelands, associated with degradation and weak control in access to land, reduces alternative feed resources and this also increases the trade-offs. The lack of access to livestock markets and alternative saving and investment options actually influence farmers' decision to keep large numbers of animals despite feed deficit, and contribute to high pressure on trade-offs (Moll, 2005; Descheemaeker et al., 2011).

Improving the targeting and adaptation of dual-purpose maize varieties and associated improvements in crop management, postharvesting, storage and feeding is one promising option to supply more quantity and quality feed in a cost-effective way, using the same labor, land and input investments as for maize grain production. Dual-purpose crops providing higher and more nutritious biomass are seen as a way to compensate for rangelands converted to croplands and poor quality of remaining rangelands (Sibanda et al., 2011). Dual-purpose maize can be introduced in relatively short term through the same channels that have promoted maize grain production and help farmers to achieve higher outputs per unit land, making greater use of the synergies between crops and livestock, especially where alternative feed options are limited (Thorne et al., 2002; Lenné et al., 2003; Tarawali et al., 2011).

The use of dual-purpose maize is only part of a set of promising technologies to improve the productivity and sustainability of mixed crop-livestock systems. Alternatively, diversifying cropland by introducing fodder technologies, e.g. silage production, dualpurpose legumes, fodder crops could also increase crop production and feed availability per unit land (Holness, 1999; Masikati, 2011). In addition, there is need for better rangeland management. Dualpurpose maize could help to reduce the pressure on this feed resource and/or supplement its degradation. This would however need substantial skills and institutional change for better regulating access to and management of the communal resources. To promote all these alternative technologies one needs to consider the poor access to these technologies, farmers' preferences for cereals as staple food, the high risk in production and low market participation.

\section{Conclusions}

This paper develops a multi-level approach for assessing the potential of dual-purpose maize technologies in southern Africa. The assessments show that there is a large potential for promoting dual-purpose maize in southern Africa. The nested landscape analysis illustrates that the potential demand for dual-purpose maize varies across and within countries and maize improvement interventions need to clearly recognize such heterogeneity. The spatial stratification by MME and demand and supply factors (RDs) can be used as simple raster for identifying areas with similar probability of dual-purpose maize adoption and extrapolation to areas with similar conditions. It is however not sufficient to assess the potential for dual-purpose maize cultivars in those areas. Further biomass assessments are required to capture the real feed supply from rangelands. Promoting dualpurpose maize as a technology that enhances productivity per unit land needs to also consider the context-specific factors and dynamics at play. From the country comparison we conclude that a higher agro-ecological potential as well as a higher demand for livestock products does not directly translate to higher demand for dual-purpose maize. A critical message is that dual-purpose maize can supply higher quality biomass at higher levels of agricultural intensification. Dual-purpose maize is equally important for the dryland areas, where there is strong presence of livestock against limited biomass quality and low maize yields. Though this integrated approach, different types of improved dual-purpose maize cultivars can be targeted to sustain intensification processes in different environments and institutional contexts.

\section{Acknowledgments}

The research received financial support from and contributed to the project on optimizing the use of crop residues, southern Africa scoping study, under the System-wide Livestock Programme (SLP, http://www.vslp.org/), of the Consultative Group of International Agricultural Research (CGIAR). We also thank the Research Program Resilient Dryland Systems for support. ICRISAT, ILRI and the national partners Bunda Agricultural College, Malawi, Mozambican Agricultural Research Institute, Mozambique, Matopos Research Institute, Zimbabwe, implemented it. We would like to acknowledge those who supported the work, especially An Notenbaert for GIS support, Swathi Sridharan for editing, and the reviewers for their constructive comments. The views expressed in this paper are the authors' and do not necessarily reflect the views of the SLP or the authors' institutions.

\section{Appendix A.}

Table A.1.

Table A.2. 
Table A.1

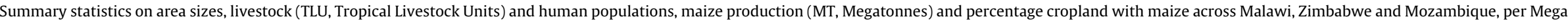
Environment and Recommendation Domain.

\begin{tabular}{lllll}
\hline RDs/MEs & \multicolumn{3}{l}{ Malawi } \\
\cline { 2 - 5 } & $\begin{array}{l}\text { Area } \\
\text { ('000 km²) }\end{array}$ & TLU ('000) & $\begin{array}{l}\text { Human } \\
\text { pop. ('000) }\end{array}$ & $\begin{array}{l}\text { Maize prod. } \\
\text { ('000 MT) }\end{array}$ \\
\hline A (Wet Upper Mid-altitude) & & \\
HHH & 3 & 53 & 195 & 1 \\
HHL & 3 & 66 & 220 & 0 \\
HLH & 1 & 21 & 14 & 0 \\
HLL & 1 & 15 & 19 & 0 \\
LHH & 3 & 21 & 242 & 12 \\
LHL & 2 & 10 & 129 & 0 \\
LLH & 1 & 4 & 17 & 0 \\
LLL & 0 & 2 & 8 & 0 \\
Total & 14 & 192 & 844 & 14
\end{tabular}

B (Wet Lower Mid-altitude)

$\mathrm{HHH} \quad 1100$

HHL

HLH

HLL

LHL

LLH

Tot

C (Dry Mid-altitude)

HHH 0

HHL

HLH

HLL

LHH

LLH

LLL

D (Wet Lowland)

$\mathrm{HHH}$

$\mathrm{HHL}$

HLH

HLL

Total 1

(Dry Lowland)

$\begin{array}{ll}\text { HHH } & 2 \\ \text { HHL } & 0 \\ \text { HLH } & 0 \\ \text { HLL } & 0 \\ \text { LHH } & 2 \\ \text { LHL } & 1 \\ \text { LLH } & 1 \\ \text { LLL } & 0 \\ \text { Total } & 5\end{array}$

$\begin{array}{ll}2 & 10 \\ 0 & \\ 0 & \\ 0 & \\ 2 & \\ 1 & \\ 1 & \\ 0 & \\ 5 & \end{array}$

$\begin{array}{rr}10 & 9 \\ 3 & 20 \\ 1 & \\ 1 & \\ 10 & 10 \\ 5 & 5 \\ 3 & 13 \\ 2 & \\ 35 & 202\end{array}$

\begin{tabular}{|c|c|}
\hline $\begin{array}{l}\% \text { cropland } \\
\text { with maize }\end{array}$ & $\begin{array}{l}\text { Area } \\
\text { ('000 km }\end{array}$ \\
\hline 51 & 2 \\
\hline 45 & 8 \\
\hline 49 & 5 \\
\hline 47 & 23 \\
\hline 50 & 0 \\
\hline 56 & 4 \\
\hline 51 & 1 \\
\hline 50 & 4 \\
\hline 50 & 47 \\
\hline
\end{tabular}

$\begin{array}{rl} & \\ \text { TLU ('000) } & \begin{array}{l}\text { Human } \\ \text { pop. ('000) }\end{array} \\ & \\ 35 & 115 \\ 104 & 338 \\ 66 & 126 \\ 333 & 628 \\ 3 & 20 \\ 25 & 191 \\ 7 & 22 \\ 26 & 90 \\ 600 & 1530\end{array}$

Maize prod. \% cropland $\quad$ Area

$\begin{array}{llll}\text { TLU('000) } & \begin{array}{l}\text { Human } \\ \text { pop. ('000) }\end{array} & \begin{array}{l}\text { Maize prod. } \\ \text { ('000 MT) }\end{array} & \begin{array}{l}\text { \% cropland } \\ \text { with maize }\end{array}\end{array}$

50

600

1530

$\begin{array}{ll} & \\ 0 & 38 \\ 0 & 37 \\ 1 & 48 \\ 1 & 33 \\ 0 & 24 \\ 0 & 31 \\ 0 & 42 \\ 0 & 29 \\ 3 & 35\end{array}$

$\begin{array}{lr}38 & 0 \\ 37 & 1 \\ 48 & 0 \\ 33 & 0 \\ 24 & 1 \\ 31 & 6 \\ 42 & 0 \\ 29 & 5 \\ 35 & 13\end{array}$

3
13
0
4
4
21
0
7
52

$\begin{array}{rll}19 & 0 & 37 \\ 73 & 0 & 65 \\ 0 & 0 & 46 \\ 5 & 0 & 53 \\ 42 & 0 & 65 \\ 300 & 0 & 49 \\ 3 & 0 & 60 \\ 91 & 0 & 42 \\ 533 & 1 & 49\end{array}$

$\begin{array}{rrll}33 & 84 & 1 & 60 \\ 106 & 286 & 0 & 37 \\ 13 & 31 & 0 & 36 \\ 258 & 494 & 0 & 25 \\ 2 & 12 & 0 & 32 \\ 3 & 26 & 0 & 23 \\ 12 & 47 & 0 & 20 \\ 31 & 113 & 0 & 29 \\ 457 & 1092 & 2 & 30\end{array}$

$\begin{array}{rrr}60 & 0 & 1 \\ 37 & 0 & 3 \\ 36 & 0 & 0 \\ 25 & 0 & 3 \\ 32 & 0 & 3 \\ 23 & 10 & 22 \\ 20 & 0 & 0 \\ 29 & 10 & 12 \\ 30 & 22 & 43\end{array}$

$\begin{array}{rll}4 & 0 & 65 \\ 20 & 0 & 56 \\ 0 & 0 & 43 \\ 3 & 0 & 41 \\ 25 & 0 & 61 \\ 497 & 0 & 37 \\ 2 & 0 & 57 \\ 154 & 0 & 34 \\ 705 & 1 & 32\end{array}$

$\begin{array}{lrrrll}0 & 2 & 21 & 63 & 0 & 50 \\ 0 & 9 & 160 & 404 & 0 & 39 \\ 0 & 3 & 53 & 85 & 2 & 63 \\ 0 & 15 & 233 & 363 & 1 & 32 \\ 0 & 0 & 1 & 4 & 0 & 40 \\ 0 & 0 & 1 & 3 & 0 & 26 \\ 0 & 1 & 3 & 11 & 0 & 60 \\ 0 & 9 & 48 & 121 & 0 & 21 \\ 0 & 38 & 519 & 1052 & 4 & 36\end{array}$

$\begin{array}{llrlr}0 & 0 & 0 & 0 & 0 \\ 0 & 6 & 29 & 0 & 40 \\ 0 & 0 & 0 & 0 & 0 \\ 0 & 0 & 0 & 0 & 84 \\ 0 & 0 & 3 & 0 & 22 \\ 0 & 2 & 26 & 0 & 31 \\ 0 & 0 & 0 & 0 & 0 \\ 0 & 0 & 1 & 0 & 46 \\ 1 & 9 & 59 & 0 & 0\end{array}$

$\begin{array}{rl}54 & 0 \\ 60 & 0 \\ 48 & 0 \\ 56 & 0 \\ 71 & 0 \\ 60 & 0 \\ 50 & 0 \\ 71 & 0 \\ 0 & 0\end{array}$

$\begin{array}{lll}0 & 0 & 0 \\ 0 & 0 & 0 \\ 0 & 0 & 0 \\ 2 & 3 & 0 \\ 0 & 0 & 0 \\ 0 & 0 & 0 \\ 0 & 0 & 0 \\ 0 & 0 & 0 \\ 2 & 3 & 0\end{array}$

0
0
0
35
0
0
0
0
0

$\begin{array}{rr}0 & 0 \\ 0 & 5 \\ 0 & 0 \\ 0 & 1 \\ 1 & 2 \\ 30 & 70 \\ 0 & 0 \\ 42 & 65 \\ 73 & 143\end{array}$

$\begin{array}{rlr}0 & 0 & 0 \\ 17 & 0 & 26 \\ 0 & 0 & 38 \\ 2 & 0 & 51 \\ 23 & 0 & 41 \\ 1502 & 1 & 24 \\ 7 & 0 & 38 \\ 1036 & 1 & 27 \\ 2588 & 2 & 26\end{array}$

$\begin{array}{rr}54 & 2 \\ 34 & 11 \\ 62 & 1 \\ 59 & 18 \\ 49 & 0 \\ 55 & 1 \\ 50 & 2 \\ 49 & 18 \\ 62 & 52\end{array}$

$\begin{array}{rrr}30 & 87 & 1 \\ 174 & 490 & 0 \\ 10 & 22 & 0 \\ 255 & 455 & 1 \\ 1 & 10 & 0 \\ 4 & 32 & 0 \\ 13 & 52 & 0 \\ 100 & 296 & 1 \\ 586 & 1443 & 3\end{array}$

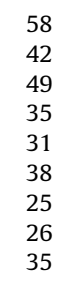

$\begin{array}{rr}0 & 0 \\ 2 & 34 \\ 0 & 1 \\ 3 & 41 \\ 0 & 1 \\ 9 & 30 \\ 0 & 1 \\ 29 & 61 \\ 43 & 170\end{array}$

$\begin{array}{rl}2 & 0 \\ 117 & 0 \\ 1 & 0 \\ 272 & 0 \\ 13 & 0 \\ 558 & 0 \\ 3 & 0 \\ 338 & 1 \\ 1303 & 1\end{array}$

28
45
33
44
37
36
41
42
41

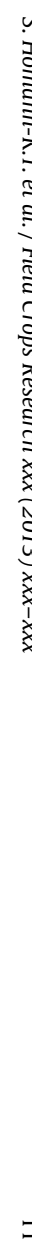


Table A.1 (Continued)

\begin{tabular}{|c|c|c|c|c|c|c|c|c|c|c|c|c|c|c|c|}
\hline \multirow[t]{2}{*}{$\mathrm{RDs} / \mathrm{MEs}^{\mathrm{a}}$} & \multicolumn{5}{|l|}{ Malawi } & \multicolumn{5}{|l|}{ Zimbabwe } & \multicolumn{5}{|c|}{ Mozambique } \\
\hline & $\begin{array}{l}\text { Area } \\
\left({ }^{\prime} 000 \mathrm{~km}^{2}\right)\end{array}$ & TLU (‘000) & $\begin{array}{l}\text { Human } \\
\text { pop. ('000) }\end{array}$ & $\begin{array}{l}\text { Maize prod. } \\
\text { ('000 MT) }\end{array}$ & $\begin{array}{l}\% \text { cropland } \\
\text { with maize }\end{array}$ & $\begin{array}{l}\text { Area } \\
\text { ('000 km²) }\end{array}$ & TLU ('000) & $\begin{array}{l}\text { Human } \\
\text { pop. ('000) }\end{array}$ & $\begin{array}{l}\text { Maize prod. } \\
\text { ('000 MT) }\end{array}$ & $\begin{array}{l}\% \text { cropland } \\
\text { with maize }\end{array}$ & $\begin{array}{l}\text { Area } \\
\left({ }^{2} 000 \mathrm{~km}^{2}\right)\end{array}$ & TLU('000) & $\begin{array}{l}\text { Human } \\
\text { pop. ('000) }\end{array}$ & $\begin{array}{l}\text { Maize prod. } \\
\text { ('000 MT) }\end{array}$ & $\begin{array}{l}\% \text { cropland } \\
\text { with maize }\end{array}$ \\
\hline \multicolumn{16}{|c|}{ F (Highland) } \\
\hline $\mathrm{HHH}$ & 0 & 6 & 22 & 0 & 35 & 0 & 4 & 16 & 0 & 39 & 0 & 1 & 8 & 0 & 46 \\
\hline HHL & 1 & 10 & 29 & 0 & 41 & 1 & 13 & 45 & 0 & 42 & 0 & 4 & 20 & 0 & 55 \\
\hline $\mathrm{HLH}$ & 0 & 6 & 8 & 0 & 43 & 0 & 4 & 8 & 0 & 49 & 0 & 0 & 0 & 0 & 0 \\
\hline HLL & 0 & 5 & 6 & 0 & 50 & 2 & 30 & 60 & 0 & 49 & 0 & 0 & 0 & 0 & 64 \\
\hline LHH & 0 & 2 & 23 & 1 & 65 & 0 & 0 & 1 & 0 & 68 & 0 & 1 & 10 & 0 & 30 \\
\hline LHL & 0 & 1 & 4 & 0 & 57 & 0 & 1 & 8 & 0 & 52 & 1 & 6 & 61 & 0 & 35 \\
\hline LLH & 0 & 1 & 5 & 0 & 40 & 0 & 0 & 0 & 0 & 70 & 0 & 0 & 1 & 0 & 69 \\
\hline LLL & 1 & 7 & 11 & 0 & 65 & 0 & 2 & 6 & 0 & 45 & 0 & 1 & 4 & 0 & 51 \\
\hline Total & 3 & 38 & 108 & 1 & 35 & 4 & 54 & 144 & 0 & 35 & 2 & 13 & 104 & 0 & 18 \\
\hline
\end{tabular}

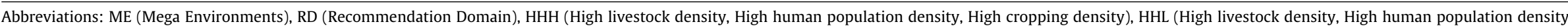

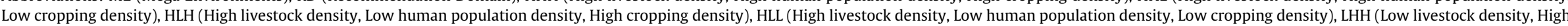

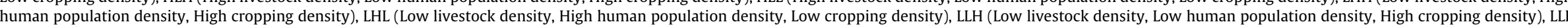
(Low livestock density, Low human population density, Low cropping density).

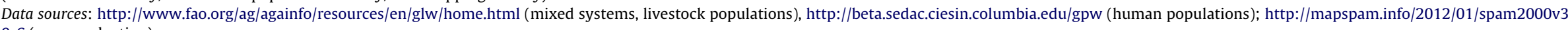
0-6 (crop production).

a RDs of the case study sites.

\section{Table A.2}

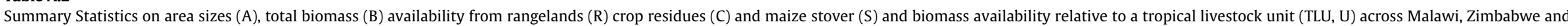
Mozambique, per Mega Environment and Recommendation Domain.

\begin{tabular}{|c|c|c|c|c|c|c|c|c|c|c|c|c|c|c|c|c|c|c|c|c|c|}
\hline \multirow[t]{2}{*}{$\mathrm{RDs} / \mathrm{MEs}^{\mathrm{a}}$} & \multicolumn{7}{|l|}{ Malawi } & \multicolumn{7}{|l|}{ Zimbabwe } & \multicolumn{7}{|c|}{ Mozambique } \\
\hline & $\begin{array}{l}\text { A } \\
(' 000) \mathrm{km}^{2}\end{array}$ & $\begin{array}{l}\mathrm{R} \\
\left({ }^{\prime} 000\right) \mathrm{t}\end{array}$ & C & $\mathrm{s}$ & $\begin{array}{l}\mathrm{C}: \mathrm{B} \\
\%\end{array}$ & $\mathrm{~S}: \mathrm{C}$ & $\begin{array}{l}\mathrm{B} / \mathrm{U} \\
\mathrm{t} / \mathrm{TLU}\end{array}$ & $\begin{array}{l}\text { A } \\
(' 000) \mathrm{km}^{2}\end{array}$ & $\mathrm{R}$ & $\begin{array}{l}\mathrm{C} \\
\left({ }^{\prime} 000\right) \mathrm{t}\end{array}$ & S & $\begin{array}{l}\mathrm{C}: \mathrm{B} \\
\%\end{array}$ & $\mathrm{~S}: \mathrm{C}$ & $\begin{array}{l}\mathrm{B} / \mathrm{U} \\
\mathrm{t} / \mathrm{TLU}\end{array}$ & $\begin{array}{l}\text { A } \\
(' 000) \mathrm{km}^{2}\end{array}$ & $\begin{array}{l}\mathrm{R} \\
\left({ }^{\prime} 000\right) \mathrm{t}\end{array}$ & C & S & $\begin{array}{l}\mathrm{C}: \mathrm{B} \\
\%\end{array}$ & $\mathrm{~S}: \mathrm{C}$ & $\begin{array}{l}\mathrm{B} / \mathrm{U} \\
\mathrm{t} / \mathrm{TLU}\end{array}$ \\
\hline \multicolumn{22}{|c|}{ A (Wet Upper Mid-altitude) } \\
\hline $\mathrm{HHH}$ & 3 & 76 & 369 & 96 & 83 & 26 & 8 & 2 & 168 & 99 & 43 & 37 & 44 & 8 & 0 & 9 & 54 & 8 & 86 & 15 & 21 \\
\hline HHL & 3 & 59 & 28 & 9 & 32 & 31 & 1 & 8 & 514 & 52 & 28 & 9 & 54 & 5 & 1 & 33 & 16 & 10 & 33 & 59 & 4 \\
\hline HLH & 1 & 33 & 66 & 24 & 67 & 36 & 5 & 5 & 328 & 538 & 92 & 62 & 17 & 13 & 0 & 1 & 2 & 0 & 67 & 3 & 31 \\
\hline HLL & 1 & 20 & 4 & 1 & 17 & 29 & 2 & 23 & 1176 & 138 & 81 & 11 & 59 & 4 & 0 & 13 & 2 & 1 & 13 & 49 & 4 \\
\hline LHH & 3 & 107 & 462 & 13 & 81 & 3 & 27 & 0 & 25 & 17 & 1 & 40 & 4 & 13 & 1 & 52 & 24 & 16 & 32 & 65 & 18 \\
\hline LHL & 2 & 36 & 16 & 7 & 31 & 43 & 5 & 4 & 275 & 31 & 6 & 10 & 20 & 12 & 6 & 304 & 30 & 18 & 9 & 59 & 16 \\
\hline LLH & 1 & 33 & 66 & 21 & 67 & 32 & 25 & 1 & 78 & 96 & 13 & 55 & 13 & 24 & 0 & 10 & 12 & 3 & 55 & 21 & 75 \\
\hline LLL & 0 & 23 & 4 & 2 & 15 & 54 & 12 & 4 & 251 & 21 & 14 & 8 & 68 & 10 & 5 & 601 & 33 & 16 & 5 & 49 & 86 \\
\hline Total & 14 & 386 & 1015 & 172 & 72 & 17 & 7 & 47 & 2816 & 991 & 279 & 26 & 28 & 6 & 13 & 1023 & 174 & 71 & 15 & 41 & 23 \\
\hline \multicolumn{22}{|c|}{ B (Wet Lower Mid-altitude) } \\
\hline $\mathrm{HHH}$ & 1 & 24 & 125 & 39 & 84 & 31 & 15 & 2 & 104 & 90 & 50 & 46 & 55 & 6 & 0 & 103 & 2 & 1 & 2 & 66 & 174 \\
\hline HHL & 0 & 7 & 3 & 2 & 30 & 58 & 2 & 6 & 265 & 33 & 14 & 11 & 41 & 3 & 0 & 37 & 4 & 2 & 10 & 46 & 12 \\
\hline HLH & 0 & 5 & 22 & 8 & 81 & 37 & 12 & 1 & 49 & 52 & 13 & 51 & 25 & 8 & 0 & 0 & 0 & 0 & 0 & 0 & 0 \\
\hline HLL & 0 & 4 & 1 & 0 & 20 & 61 & 2 & 18 & 620 & 53 & 27 & 8 & 50 & 3 & 0 & 10 & 1 & 0 & 9 & 47 & 4 \\
\hline LHH & 3 & 79 & 338 & 108 & 81 & 32 & 26 & 0 & 19 & 19 & 0 & 50 & 1 & 20 & 0 & 23 & 11 & 6 & 32 & 58 & 13 \\
\hline LHL & 2 & 37 & 13 & 5 & 26 & 36 & 5 & 1 & 22 & 1 & 0 & 4 & 10 & 8 & 10 & 720 & 38 & 19 & 5 & 50 & 35 \\
\hline LLH & 1 & 27 & 62 & 22 & 70 & 36 & 32 & 2 & 118 & 72 & 26 & 38 & 36 & 16 & 0 & 9 & 7 & 2 & 44 & 22 & 81 \\
\hline LLL & 1 & 20 & 4 & 1 & 17 & 35 & 10 & 5 & 351 & 45 & 29 & 11 & 64 & 13 & 10 & 1318 & 54 & 26 & 4 & 49 & 113 \\
\hline Total & 7 & 204 & 568 & 185 & 74 & 33 & 15 & 35 & 1549 & 366 & 159 & 19 & 43 & 4 & 22 & 2219 & 116 & 57 & 5 & 49 & 54 \\
\hline
\end{tabular}


Table A.2 (Continued)

\begin{tabular}{|c|c|c|c|c|c|c|c|c|c|c|c|c|c|c|c|c|c|c|c|c|c|}
\hline \multirow[t]{2}{*}{$\mathrm{RDs} / \mathrm{MEs}^{\mathrm{a}}$} & \multicolumn{7}{|l|}{ Malawi } & \multicolumn{7}{|l|}{ Zimbabwe } & \multicolumn{7}{|c|}{ Mozambique } \\
\hline & $\begin{array}{l}\mathrm{A} \\
\left({ }^{\prime} 000\right) \mathrm{km}^{2}\end{array}$ & $\begin{array}{l}\mathrm{R} \\
\left({ }^{\prime} 000\right) \mathrm{t}\end{array}$ & C & $\mathrm{S}$ & $\begin{array}{l}\mathrm{C}: \mathrm{B} \\
\%\end{array}$ & $\mathrm{~S}: \mathrm{C}$ & $\begin{array}{l}\mathrm{B} / \mathrm{U} \\
\mathrm{t} / \mathrm{TLU}\end{array}$ & $\begin{array}{l}\text { A } \\
(\cdot 000) \mathrm{km}^{2}\end{array}$ & $\mathrm{R}$ & $\begin{array}{l}\mathrm{C} \\
(' 000) \mathrm{t}\end{array}$ & $S$ & $\begin{array}{l}\mathrm{C}: \mathrm{B} \\
\%\end{array}$ & $\mathrm{~S}: \mathrm{C}$ & $\begin{array}{l}\mathrm{B} / \mathrm{U} \\
\mathrm{t} / \mathrm{TLU}\end{array}$ & $\begin{array}{l}\mathrm{A} \\
\left({ }^{\prime} 000\right) \mathrm{km}^{2}\end{array}$ & $\begin{array}{l}\mathrm{R} \\
(' 000) \mathrm{t}\end{array}$ & C & $S$ & $\begin{array}{l}\mathrm{C}: \mathrm{B} \\
\%\end{array}$ & $\mathrm{~S}: \mathrm{C}$ & $\begin{array}{l}\mathrm{B} / \mathrm{U} \\
\mathrm{t} / \mathrm{TLU}\end{array}$ \\
\hline \multicolumn{22}{|c|}{ C (Dry Mid-altitude) } \\
\hline $\mathrm{HHH}$ & 0 & 0 & 0 & 0 & 0 & 0 & 0 & 2 & 71 & 68 & 43 & 49 & 64 & 7 & 0 & 0 & 0 & 0 & 0 & 0 & 0 \\
\hline HHL & 0 & 0 & 0 & 0 & 0 & 0 & 0 & 9 & 226 & 63 & 30 & 22 & 47 & 2 & 0 & 12 & 3 & 1 & 20 & 50 & 2 \\
\hline HLH & 0 & 0 & 0 & 0 & 0 & 0 & 0 & 3 & 67 & 255 & 221 & 79 & 87 & 6 & 0 & 0 & 0 & 0 & 0 & 0 & 0 \\
\hline HLL & 0 & 0 & 0 & 0 & 0 & 0 & 0 & 15 & 509 & 0 & 0 & 0 & 0 & 2 & 0 & 0 & 0 & 0 & 0 & 100 & 0 \\
\hline LHH & 0 & 0 & 0 & 0 & 0 & 0 & 0 & 0 & 6 & 5 & 4 & 45 & 77 & 18 & 0 & 0 & 0 & 0 & 0 & 2 & 2 \\
\hline LHL & 0 & 0 & 0 & 0 & 0 & 0 & 0 & 0 & 5 & 1 & 0 & 17 & 46 & 11 & 0 & 10 & 1 & 0 & 9 & 14 & 6 \\
\hline LLH & 0 & 0 & 0 & 0 & 0 & 0 & 0 & 1 & 32 & 18 & 17 & 36 & 91 & 15 & 0 & 0 & 0 & 0 & 0 & 0 & 0 \\
\hline LLL & 0 & 0 & 0 & 0 & 0 & 0 & 0 & 9 & 410 & 45 & 27 & 10 & 59 & 9 & 0 & 5 & 0 & 0 & 0 & 58 & 25 \\
\hline Total & 0 & 0 & 0 & 0 & 0 & 0 & 0 & 38 & 1325 & 455 & 341 & 26 & 75 & 3 & 1 & 27 & 4 & 2 & 13 & 38 & 4 \\
\hline \multicolumn{22}{|c|}{ D (Wet Lowland) } \\
\hline $\mathrm{HHH}$ & 0 & 2 & 6 & 3 & 75 & 58 & 12 & 0 & 0 & 0 & 0 & 0 & 0 & 0 & 0 & 0 & 7 & 0 & 100 & 2 & 0 \\
\hline HHL & 0 & 0 & 0 & 0 & 0 & 82 & 3 & 0 & 0 & 0 & 0 & 0 & 0 & 0 & 0 & 32 & 3 & 0 & 9 & 6 & 7 \\
\hline HLH & 0 & 0 & 1 & 1 & 100 & 75 & 5 & 0 & 0 & 0 & 0 & 0 & 0 & 0 & 0 & 0 & 0 & 0 & 0 & 50 & 0 \\
\hline HLL & 0 & 1 & 0 & 0 & 0 & 50 & 6 & 0 & 3 & 0 & 0 & 5 & 82 & 2 & 0 & 5 & 0 & 0 & 0 & 47 & 3 \\
\hline LHH & 0 & 15 & 36 & 12 & 71 & 33 & 8 & 0 & 0 & 0 & 0 & 0 & 0 & 0 & 1 & 75 & 24 & 11 & 24 & 45 & 58 \\
\hline LHL & 0 & 1 & 0 & 0 & 0 & 70 & 6 & 0 & 0 & 0 & 0 & 0 & 0 & 0 & 30 & 4056 & 229 & 67 & 5 & 29 & 61 \\
\hline LLH & 0 & 6 & 10 & 2 & 63 & 24 & 20 & 0 & 0 & 0 & 0 & 0 & 0 & 0 & 0 & 46 & 15 & 4 & 25 & 29 & 152 \\
\hline LLL & 0 & 1 & 0 & 0 & 0 & 64 & 0 & 0 & 0 & 0 & 0 & 0 & 0 & 0 & 42 & 6817 & 289 & 122 & 4 & 42 & 109 \\
\hline Total & 1 & 25 & 54 & 19 & 68 & 35 & 10 & 0 & 3 & 0 & 0 & 0 & 82 & 2 & 73 & 11,031 & 567 & 205 & 5 & 36 & 81 \\
\hline \multicolumn{22}{|c|}{ E (Dry Lowland) } \\
\hline $\mathrm{HHH}$ & 2 & 14 & 44 & 16 & 76 & 37 & 6 & 2 & 76 & 103 & 59 & 58 & 57 & 0 & 0 & 3 & 7 & 0 & 70 & 2 & 25 \\
\hline HHL & 0 & 10 & 2 & 1 & 0 & 46 & 4 & 11 & 411 & 83 & 44 & 17 & 54 & 0 & 2 & 159 & 14 & 7 & 8 & 51 & 5 \\
\hline HLH & 0 & 2 & 4 & 2 & 67 & 56 & 10 & 1 & 43 & 34 & 22 & 44 & 64 & 0 & 0 & 2 & 6 & 0 & 75 & 0 & 7 \\
\hline HLL & 0 & 2 & 0 & 0 & 0 & 52 & 4 & 18 & 772 & 96 & 56 & 11 & 59 & 3 & 3 & 220 & 13 & 4 & 6 & 32 & 6 \\
\hline LHH & 2 & 104 & 220 & 61 & 68 & 28 & 32 & 0 & 12 & 4 & 1 & 25 & 28 & 0 & 0 & 13 & 23 & 0 & 64 & 2 & 30 \\
\hline LHL & 1 & 48 & 9 & 4 & 16 & 42 & 11 & 1 & 56 & 7 & 4 & 11 & 59 & 0 & 9 & 977 & 63 & 23 & 6 & 36 & 35 \\
\hline LLH & 1 & 37 & 59 & 21 & 61 & 35 & 30 & 2 & 100 & 49 & 28 & 33 & 58 & 0 & 0 & 2 & 25 & 2 & 93 & 9 & 39 \\
\hline LLL & 0 & 2 & 3 & 1 & 60 & 43 & 2 & 18 & 1049 & 97 & 52 & 8 & 53 & 0 & 29 & 2722 & 114 & 49 & 4 & 43 & 46 \\
\hline Total & 5 & 220 & 340 & 106 & 61 & 31 & 16 & 52 & 2518 & 473 & 267 & 16 & 56 & 5 & 43 & 4098 & 265 & 85 & 6 & 32 & 26 \\
\hline \multicolumn{22}{|c|}{ F (Highland) } \\
\hline $\mathrm{HHH}$ & 0 & 10 & 43 & 8 & 81 & 18 & 9 & 0 & 9 & 4 & 2 & 31 & 58 & 3 & 0 & 2 & 14 & 2 & 88 & 17 & 12 \\
\hline HHL & 1 & 9 & 4 & 1 & 0 & 29 & 1 & 1 & 34 & 4 & 2 & 11 & 58 & 3 & 0 & 68 & 1 & 0 & 1 & 31 & 19 \\
\hline $\mathrm{HLH}$ & 0 & 10 & 21 & 4 & 68 & 21 & 5 & 0 & 3 & 0 & 0 & 0 & 63 & 1 & 0 & 0 & 0 & 0 & 0 & 0 & 0 \\
\hline HLL & 0 & 6 & 1 & 1 & 14 & 36 & 1 & 2 & 88 & 7 & 5 & 7 & 75 & 3 & 0 & 2 & 0 & 0 & 0 & 77 & 5 \\
\hline LHH & 0 & 14 & 71 & 10 & 84 & 14 & 42 & 0 & 0 & 0 & 0 & 0 & 7 & 3 & 0 & 2 & 20 & 3 & 91 & 16 & 24 \\
\hline LHL & 0 & 2 & 0 & 0 & 0 & 53 & 6 & 0 & 4 & 0 & 0 & 0 & 61 & 7 & 1 & 24 & 5 & 3 & 17 & 53 & 5 \\
\hline LLH & 0 & 9 & 19 & 3 & 68 & 18 & 21 & 0 & 0 & 0 & 0 & 0 & 0 & 0 & 0 & 1 & 1 & 0 & 50 & 1 & 20 \\
\hline LLL & 1 & 3 & 1 & 0 & 25 & 60 & 0 & 0 & 37 & 3 & 3 & 8 & 81 & 24 & 0 & 27 & 2 & 1 & 7 & 55 & 32 \\
\hline Total & 3 & 63 & 160 & 28 & 72 & 17 & 6 & 4 & 177 & 19 & 13 & 10 & 67 & 4 & 2 & 125 & 44 & 10 & 26 & 23 & 13 \\
\hline
\end{tabular}

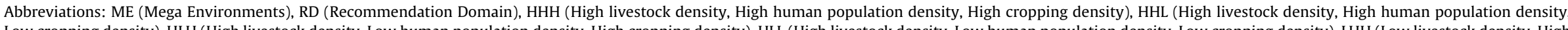

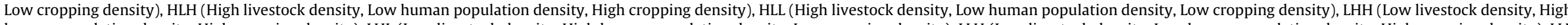

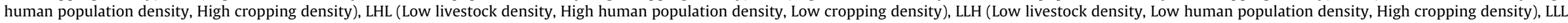
(Low livestock density, Low human population density, Low cropping density).

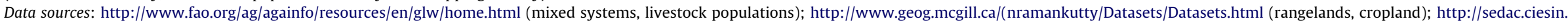

columbia.edu/gpw (NPP); http://mapspam.info/2012/01/spam2000v3-0-6 (crop production).

${ }^{a}$ RDs of the case study sites. 


\section{References}

Alkemade, R., Reid, R.S., van den Berg, M., de Leeuw, J., Jeuken, M., 2012. Assessing the impacts of livestock production on biodiversity in rangeland ecosystems. www.pnas.org/cgi/doi/10.1073/pnas.1011013108

Amede, T., Descheemaeker, K., Peden, D., van Rooyen, A., 2009. Harnessing benefits from improved livestock water productivity in crop-livestock systems of subSaharan Africa: synthesis. The Rangel. J. 31, 169-178.

AU (African Union), 2006. Declaration of the Abuja Food Security Summit: Summit on Food Security in Africa, December 4-7, 2006 Abuja, Nigeria Retrieved December 19, 2012, from www.africa-union.org

Baltenweck, I., Staal, S., Ibrahim, M.N.M., Herrero, M., Holmann, F., Jabbar, M., Manyong, V., Patil, B.R., Thornton, P.K., Williams, T., Waithaka, M., de Wolf, T., 2003. Crop-Livestock Intensification and Interaction across Three Continents. CGIAR Systemwide Livestock Program, ILRI, Addis Ababa, Main Report.

Bellon, M.R., Hodson, D., Bergvinson, D., Beck, D., Martinez-Romero, E., Montoya, Y., 2005. Targeting agricultural research to benefit poor farmers: relating poverty mapping to maize environments in Mexico. Food Policy 30, 476-492.

Berhanu, T., Habtamu, Z., Twumasi-Afriyie, S., Blümmel, M., Friesen, D., Mosisa, W., Dagne, W., Legesse, W., Girum, A., Tolera, K., Wende, A., 2012. Breeding maize for food-feed traits in Ethiopia. In: Worku, M., Twumasi-Afriyie, S., Wolde, L., Tadesse, B., Demisie, G., Bogale, G., Wegari, D., Prasanna, B.M. (Eds.), Ethiopia Meeting the Challenges of Global Climate Change and Food Security through Innovative Maize Research. Proceedings of the Third National Maize Workshop of Ethiopia. 18-20 April 2011. EIAR/CIMMYT, Addis Ababa, pp. 74-80.

Berhanu, T., Zeleke, H., Friesen, D., Blümmel, M., Twumasi-Afriyie, S., 2013. Relationship between the performance of parental inbred lines and hybrids for food-feed traits in maize in Ethiopia. Field Crops Res., http://dx.doi.org/10.1016/j.fcr.2012.12.019.

Blümmel, M., Lukuyu, B., Zaidi, P.H., Duncan, A.J., Tarawali, S.A., 2012. Dual-purpose crop development fodder trading and processing options for improved feed value chains. In: Worku, M., Twumasi-Afriyie, S., Wolde, L., Tadesse, B., Demisie, G., Bogale, G., Wegari, D., Prasanna, B.M. (Eds.), Ethiopia Meeting the Challenges of Global Climate Change and Food Security through Innovative Maize Research. Proceedings of the Third National Maize Workshop of Ethiopia. 18-20 April 2011. EIAR/CIMMYT, Addis Ababa, pp. 80-86.

Bredon, R.M., Stewart, P.G., amnd Dugmore, T.J., 1987. A manual on the nutritive value and chemical composition of commonly used South African feeds. Dept. Agric. \& Water Supply, KwaZulu-Natal Region.

Calcaterra, M., 2002. Econometric Analysis of the Structure of the Regional Maize Sector in Southern Africa. University of Pretoria, Pretoria, M.Sc. (Agric.) Thesis.

Center for International Earth Science Information Network (CIESIN), IFPRI, The World Bank, CIAT, 2004. Global Rural-Urban Mapping Project (GRUMP), Alpha Version. Socioeconomic Data and Applications Center (SEDAC). Columbia University, Palisades, NY, http://beta.sedac.ciesin.columbia.edu/gpw

Chilonda, P., Minde, I., 2007. Agriculture growth trends in Southern Africa. ReSAKSSSA Policy Brief 1. In: Pretoria, South Africa: Regional Strategic Analysis and Knowledge Support System for Southern Africa (ReSAKSS-SA). IWMI/ICRISAT, Pretoria.

Chilonda, P., Olubode-Awosola, O.O., Minde, I., 2008. Recent Trends and Future Prospects for Agricultural Growth, Poverty Reduction and Investment in Southern Africa. In: ReSAKSS-SA Annual Trends Report 2008. ICRISAT, IFPRI and IWMI, Pretoria.

De Leeuw, P.N., 1997. Crop residues in tropical Africa: trends in supply, demand and use. In: Renard, C. (Ed.), Crop Residues in Sustainable Mixed Crop/Livestock Farming Systems. CAB, ICRISAT and ILRI, Wallingford, UK, pp. 41-78.

De Leeuw, P.N., Tothill, J.C., 1990. The Concept of Rangeland Carrying Capacity in Sub-Saharan Africa: Myth or Reality? Paper 29b of the Pastoral Development Network. ODI, London.

Delgado, C., Rosegrant, C., Steinfeld, H., Ehui, S., Courbois, C., 1999. Livestock to 2020: the next food revolution. In: Food, Agriculture and the Environment Discussion Papers 28. IFPRI, FAO, ILRI, Washington, DC, Rome, Nairobi.

Descheemaeker, K., Amede, T., Haileslassie, A., Bossio, D., 2011. Analysis of gaps and possible interventions for improving water productivity in crop-livestock systems of Ethiopia. Exp. Agric. 47 (Suppl. S1), 21-38.

Grant, W., Wolfaardt, A., Louw, A., 2012. Maize Value Chain in the SADC Region. Southern Africa trade hup. AECOM International Development, USAID Southern Africa. Gabarone, Technical Report.

Hartkamp, A.D., White, J.W., Rodriguez Aguilar, A., Banziger, M., Srinivasan, G., Granados, G., Crossa, J., 2000. Maize Production Environments Revisited: a GIS Based Approach. CIMMYT, Mexico, D.F.

Holness, D.H., 1999. Strategies for dry season feeding of animals in Central and Southern Africa. In: Proceedings of a joint ZSAP/FAO workshop held in Harare, 25-27 October 1999. FAO, Harare.

Homann-Kee Tui, S., Tanganyika, J., Bandason, E., Maute, F., Nkomboni, D., Mpofu, N., Nisrane, F., van Rooyen, A.F., Gondwe, T., Dias, P., Ncube, S., Moyo, S., Hendricks, S., 2012. Optimizing livelihood and environmental benefits from crop residues in smallholder crop-livestock systems in sub-Saharan Africa and South Asia: Southern Africa case study. In: Regional SLP Report on the Socio-Economic Analysis. ICRISAT, Bulawayo.

ICRISAT, 2012. ICRISAT Eastern and Southern Africa 2011 Highlights. Crop-Livestock Intensification in Zimbabwe: Closing the Loop to Sustainability. ICRISAT, Nairobi.
Kassie, G.T., Erenstein, O., Mwangi, W., La Rovere, R., Setimela, P., Langyintuo, A. 2012. Characterization of maize production in Southern Africa: Synthesis of CIMMYT/DTMA Household Level Farming System Surveys in Angola, Malawi, Mozambique, Zambia and Zimbabwe. Socio-Economics Program Working Paper 4. CIMMYT, Mexico, D. F.

Langyintuo, A.S., Mwangi, W., Diallo, A.O., MacRobert, J., Dixon, J., Banziger, M., 2008 An Analysis of the Bottlenecks Affecting the Production and Deployment of Maize Seed in Eastern and Southern Africa. CIMMYT, Harare.

Lenné, J.M., Fernandez-Rivera, S., Blümmel, M., 2003. Approaches to improve the utilization of food-feed crops - synthesis. Field Crops Res. 84 213-222.

Masikati, P., 2011. Improving the water productivity of integrated crop-livestock systems in the semi-arid tropics of Zimbabwe: ex-ante analysis using simulation modeling. ZEF, Bonn, Ph.D. Thesis.

McDonald, P., Greenhalgh, J.F.D., Morgan, C.A., Edwards, R.A., Sinclair, L., Wilkinson, S., 2011. Animal Nutrition, seventh ed. Pearson, London.

Moll, H.A.J., 2005. Costs and benefits of livestock systems and the role of market and nonmarket relationships. Agric. Econ. 32, 181-193.

Nin Pratt, A., Diao, X., 2008. Exploring growth linkages and market opportunities for agriculture in Southern Africa. J. Econ. Integr. 23 (1) 104-137.

Notenbaert, A., Herrero, M., De Groote, H., You, L., Gonzalez-Estrada, E., Blïmmel, M. 2012. Identifying recommendation domains for targeting dual-purpose maizebased interventions in crop-livestock systems in East Africa. Land Use Policy 30 (1), 834-846.

Ojiem, J.O., de Ridder, N., Vanlauwe, B., Giller, K.E., 2006. Socio-ecological niche: a conceptual framework for integration of legumes in smallholder farming systems. Int. J. Agric. Sust. 4, 79-93.

Omamo, S., Diao, X., Wood, S., Chamberlin, J., You, L., Benin, S., Wood-Sichra U., Tatwangire, A., 2006. Strategic Priorities for Agricultural for Agricultura Development in Eastern and Central Africa. IFPRI/ASARECA, Washington, D.C, Research Report 150.

Pender, J., Place, F., Ehui, S. (Eds.), 2006. Strategies for sustainable land management in the East African highlands. IFPRI, Washington, D.C..

Ramana Reddy, R., Ravi, D., Ramakrishna Reddy, Ch., Prasad, K.V.S.V., Zaidi, P.H., Vinayan, M.T., Blümmel, M., 2013. A note on the correlations between maize grain and maize stover quantitative and qualitative traits and the implications for whole maize plant optimization. Field Crops Res. http://dx.doi.org/10.1016/j.fcr.2013.06.013.

Ramankutty, N., Evan, A.T., Monfreda, C., Foley, J.A., 2008. Geographic distribution of global agricultural lands in the year 2000. Global Biochemical Cycles. 22. GB 1003. http://dx.doi.org/10.1029/2007GB002952. http://www.geog.mcgill.ca/ nramankutty/Datasets/Datasets.html

Ravi, D., Khan, A.A., Saibutcharao, M., Blümmel, M., 2013. A note on suitable laboratory stover quality traits for multidimensional maize improvement. Field Crops Res. 150, 1-5, http://dx.doi.org/10.1016/j.fcr.2013.01.013.

Robinson, T.P., Thornton, P.K., Franceschini, G., Kruska, R.L., Chiozza, F., Notenbaert, A., Cecchi, G., Herrero, M., Epprecht, M., Fritz, S., You, L., Conchedda, G. See, L., 2011. Global Livestock Production Systems. FAO, ILRI, Rome, Nairobi, http://www.fao.org/ag/againfo/resources/en/glw/home

Sharma, K., Pattanaik, A.K., Anandan, S., Blümmel, M., 2010. Food-Feed crops research: a synthesis. Animal Nutr. Feed Techn. 10S, 1-10.

Sibanda, A., Homann-Kee Tui, S., Van Rooyen, A., Dimes, J., Nkomboni, D., Sisito G., 2011. Understanding user communities perceptions of land use changes in the rangelands, Zimbabwe. Exp. Agric. 47 (S1), 153-168 (Cambridge University Press 2010, Cambridge, http://dx.doi.org/10.1017/S001447971000092X).

Smale, M., Byerlee, D., Jayne, T., 2011. Maize revolutions in sub-Saharan Africa. In: Policy Research Working Paper 5659. The World Bank Development Research Group Agriculture and Rural Development Team, Washington, D.C.

Spatial Production Allocation Model (SPAM) SPAM., 2000, v3.0.r6. http://mapspam. info/.2012/01/spam2000v3-0-6

Tarawali, S., Herrero, M., Descheemaeker, K., Grings, E., Blümmel, M., 2011 Pathways for sustainable development of mixed crop-livestock systems: taking a livestock and pro-poor approach. Livestock Sci. 139 (1-2) $11-21$.

Thorne, P.J., Thornton, P.K., Kruska, R.L., Reynolds, L., Waddington, S.R., Rutherford, A.S., Odero, A.N., 2002. Maize as food, feed and fertilizer in intensifying mixed crop-livestock systems in East and southern Africa: an ex-ante impact assessment of technology interventions to improve smallholder welfare. ILRI Impact Assessment Series, 11. ILRI, Nairobi.

Thornton, P.K., Kruska, R.L., Henninger, N., Kristjanson, P.M., Reid, R.S., Atieno, F. Odero, A., Ndegwa, T., 2002. Mapping poverty and livestock in the developing world. ILRI, Nairobi.

Valbuena, D., Erenstein, O., Homann-Kee Tui, S., Abdoulaye, T., Lieven, C., Duncan, A.J., Gérard, B., Rufino, M., Teufel, N., van Rooyen, A., van Wijk, M.T. 2012. Conservation Agriculture in mixed crop-livestock systems: scoping crop residue trade-offs in Sub-Saharan Africa and South Asia. Field Crops Res. 132, 175-184.

Van Soest, P.J., 1994. Nutritional Ecology of the Ruminant, second ed. University Press, Cornell.

Williams, T.O., 1994. Identifying target groups for livestock improvement research: the classification of sedentary livestock producers in western Niger. Agric. Syst. 46, 227-237.

Wint, G., Robinson, T., 2007. Gridded livestock of the world 2007. FAO, Rome

World Bank, FAO, ILRI, AU-IBAR., 2013. Investing in African Livestock: business opportunities in 2030-2050. Livestock Data Innovation in Africa Project. A joint 
initiative of the World Bank, FAO, ILRI, AU-IBAR with support from the Bill and Melinda Gates Foundation. www.fao.org/docrep/018/al757e/al757e.pdf

Zaidi, P.H., Vinayan, M.T., Blümmel, M., 2012. Genetic variability of maize stover quality and the potential for genetic improvement of food-feed value in India. Field Crops Res., http://dx.doi.org/10.1016/j.fcr.2012.11.020.

Zhao, M., Running, S.W., 2010. Drought-induced reduction in global terrestrial net primary production from 2000 through 2009. Science 329, 940-943, http://sedac.ciesin.columbia.edu/gpw
Zhao, M., Heinsch, F.A., Nemani, R.R., Running, S.W., 2005. Improvements of the MODIS terrestrial gross and net primary production global data set. Remote Sensing Environ. 95, 164-176.

Zhao, M., Running, S.W., Nemani, R.R., 2006. Sensitivity of Moderate Resolution Imaging Spectroradiometer (MODIS) terrestrial primary production to the accuracy of meteorological analyses. J. Geophysical Res. 111, G01002, http://dx.doi.org/10.1029/2004JG000004.

Please cite this article in press as: Homann-K.T., S., et al., Assessing the potential of dual-purpose maize in southern Africa: A multi-level approach. Field Crops Res. (2013), http://dx.doi.org/10.1016/j.fcr.2013.07.002 